\title{
Recombinant Lipoprotein Rv1016c Derived from Mycobacterium tuberculosis Is a TLR-2 Ligand that Induces Macrophages Apoptosis and Inhibits MHC II Antigen Processing
}

\author{
Haibo Su ${ }^{1,2,3,4 *}$, Shenglin Zhu ${ }^{3}$, Lin Zhu ${ }^{3}$, Wei Huang ${ }^{1,2}$, Honghai Wang ${ }^{3}$, Zhi Zhang ${ }^{4 *}$ and \\ Ying $X u^{3 *}$ \\ ${ }^{1}$ CAS Key Laboratory of Regenerative Biology, Joint of School of Life Science, Guangzhou Medical University, Guangzhou, \\ China, ${ }^{2}$ Guangzhou Institutes of Biomedicine and Health, Chinese Academy of Sciences, Guangzhou, China, ${ }^{3}$ State Key \\ Laboratory of Genetic Engineering, Institute of Genetics, School of Life Science, Fudan University, Shanghai, China, \\ ${ }^{4}$ Department of Clinical Laboratory, Second People's Hospital of Guangdong Province, Guangzhou, China
}

\section{OPEN ACCESS}

Edited by:

Francois Vandenesch,

University of Lyon, France

Reviewed by:

Geanncarlo Lugo-Villarino, Institute of Pharmacology and Structural Biology (CNRS), France

Eric Ghigo,

Centre National de la Recherche

Scientifique, France

*Correspondence:

Haibo Su

suhaibo899@gzhmu.edu.cn

Zhi Zhang

zhangzhi@163.com

Ying Xu

yingxu2520@fudan.edu.cn

Received: 16 June 2016

Accepted: 25 October 2016

Published: 18 November 2016

Citation:

Su H, Zhu S, Zhu L, Huang W Wang H, Zhang Z and Xu Y (2016) Recombinant Lipoprotein Rv1016c

Derived from Mycobacterium tuberculosis Is a TLR-2 Ligand that Induces Macrophages Apoptosis and Inhibits MHC II Antigen Processing. Front. Cell. Infect. Microbiol. 6:147. doi: 10.3389/fcimb.2016.00147
TLR2-dependent cellular signaling in Mycobacterium tuberculosis-infected macrophages causes apoptosis and inhibits class II major histocompatibility complex (MHC-II) molecules antigen processing, leading to evasion of surveillance. Mycobacterium tuberculosis (MTB) lipoproteins are an important class of Toll-like receptor (TLR) ligand, and identified as specific components that mediate these effects. In this study, we identified and characterized MTB lipoprotein Rv1016c (IpqT) as a cell wall associated-protein that was exposed on the cell surface and enhanced the survival of recombinants M. smegmatis_Rv1016c under stress conditions. We found that Rv1016c lipoprotein was a novel TLR2 ligand and able to induce macrophage apoptosis in a both dose- and time-dependent manner. Additionally, apoptosis induced by Rv1016c was reserved in THP-1 cells blocked with anti-TLR-2 Abs or in TLR2 ${ }^{-1-}$ mouse macrophages, indicating that Rv1016c-induced apoptosis is dependent on TLR2. Moreover, we demonstrated that Rv1016c lipoprotein inhibited IFN- $\gamma$-induced MHC-II expression and processing of soluble antigens in a TLR2 dependent manner. Class II transactivator (CIITA) regulates MHC II expression. In this context, Rv1016c lipoprotein diminished IFN- $\gamma$-induced expression of CIITA IV through TLR2 and MAPK Signaling. TLR2-dependent apoptosis and inhibition of MHC-II Ag processing induced by Rv1016c during mycobacteria infection may promote the release of residual bacilli from apoptotic cells and decrease recognition by $\mathrm{CD}^{+}{ }^{+} \mathrm{T}$ cells. These mechanisms may allow intracellular MTB to evade immune surveillance and maintain chronic infection.

Keywords: Rv1061c, MHC II, Mycobacterium tuberculosis, TLR2, apoptosis

\section{INTRODUCTION}

Mycobacterium tuberculosis (MTB) is considered to be the significant cause of mortality worldwide, especially due to its ability to resistant antibiotic and co-infected with HIV patients (Bruchfeld et al., 2015; Dheda et al., 2016). Host resistance against MTB infection depends on both innate and adaptive immunity, and the emerging evidences in mammals have indicated that $\mathrm{CD} 4^{+} \mathrm{T}$ cells 
initiates the adaptive response and are critical to control of MTB infection, although $\mathrm{CD}^{+} \mathrm{T}$ cells are also involved (Torrado and Cooper, 2011; Jasenosky et al., 2015). However, MTB remains to survival within infected macrophages for prolonged periods by evading the elimination of host immune responses (Holvast et al., 2010; Dorhoi and Kaufmann, 2014). The molecular basis that allow MTB to persist for years in the face of vigorous $\mathrm{CD} 4^{+} \mathrm{T}$ cell responses may involve the decreased antigen processing or MHC-II expression in infected macrophages, which prevented the recognition of infected macrophages by effector $\mathrm{CD} 4^{+} \mathrm{T}$ cells (Noss et al., 2000; Kaufmann et al., 2016). Actually, MTB indeed can inhibit antigen processing by murine macrophages via a mechanism involving decreased synthesis of MHC-II molecules, consistent with other reports of the ability of mycobacteria to decrease MHC-II expression by infected cells (Kaufmann and Schaible, 2005; Pecora et al., 2009; Satchidanandam et al., 2014).

Mycobacterium tuberculosis was capable of inducing macrophages to undergo apoptosis in vitro. Recently, emerging interest has arisen in the role of macrophage apoptosis in host defense against MTB infection (Keane et al., 2000). However, A variety of questions including the characterization of the responsible microbial factors and the underlying apoptotic mechanism involved remain unresolved. Knowledge about the mechanisms involved in the apoptosis of mycobacteriainfected macrophages suggested that M. tuberculosis could interact with macrophages and induced apoptosis through TLR signaling (Means et al., 2001). TLR-2 has been demonstrated to recognize $M$. tuberculosis or its subcellular fractions and activate intracellular apoptotic signaling. A few of molecularly diverse mycobacterial products involved in macrophage apoptosis have been identified; among these are $19-\mathrm{kDa}$ lipoprotein (Lopez et al., 2003), ESAT6 (Derrick and Morris, 2007), lipomannan (Dao et al., 2004), and 38-kDa lipoprotein (Sanchez et al., 2009). Identification of $M$. tuberculosis factors responsible for inducing apoptosis will facilitate the understanding of pathogenesis and may provide novel strategies for MTB prevention or treatment.

TLR2 on APCs are critical for host protection and immunopathology, particular in host APCs sensing mycobacteria (Kleinnijenhuis et al., 2011). Previous studies showed that deficiency in TLR2 could enhance the susceptibility of mice to mycobacterial infection (Reiling et al., 2002; Gomes et al., 2004). The TLR2 polymorphisms in human are also associated with increased susceptibility to tuberculosis (Ogus et al., 2004; Texereau et al., 2005; Dalgic et al., 2011). So far, several mycobacterial ligands including lipoproteins have been found to bind to TLR2 (Pennini et al., 2006; Shi et al., 2009). MTB lipoproteins have either stimulatory or inhibitory effects on host antigen presenting cells (APCs), some of which are TLR2 dependent (Harding and Boom, 2010). Lipoprotein MPT83, a TLR2 ligand, promoted IFN- $\gamma$-induced MHC II expression and enhanced the ability of macrophages to present the MPT83

Abbreviations: Ms, M. smegmatis; TLR, Toll-like receptors; TB, tuberculosis; MTB, Mycobacterium tuberculosis; LPS, Lipopolysaccharides; CFU, colonyforming unit; SDS-PAGE, sulfate-polyacrylamide gel electrophoresis; ELISA, enzyme-linked immune sorbent assay; MHC, histocompatibility complex; IFN- $\gamma$, Interferon gamma; Pam3, Pam3CSK4. peptide to $\mathrm{CD}^{+} \mathrm{T}$ by (Chen et al., 2012). However, prolonged exposure to other lipoproteins such as Lpr A, Lpr G as well as $19-\mathrm{kDa}$ lipoproteins inhibited IFN- $\boldsymbol{\gamma}$-induced MHC-II expression and antigen presentation via TLR2 (Pecora et al., 2006; Drage et al., 2010). Additionally, MTB lipoproteins inhibited several IFN- $\gamma$-induced immune function genes expression including II transactivator (CIITA), which regulates MHC II transcription, H2-M, and other accessory proteins required for Ag presentation, potentially inhibiting responses by $\mathrm{CD}^{+} \mathrm{T}$ cells that produce IFN- $\gamma$ (Noss et al., 2001). Consequently, a small group of infected macrophages with attenuated APC function may induce anti-inflammatory cytokines and be unable to present $\mathrm{MTB}$ antigens to $\mathrm{CD}^{+} \mathrm{T}$ cells, providing a kind of mechanism by which MTB consistently persists and evades immune surveillance (Richardson et al., 2015).

Regulation of MHC-II expression or antigen processing can be achieved by exposure of macrophages to MTB components, which initiates responses by APCs that regulate both innate and adaptive immunity (De Lerma Barbaro et al., 1999). So far, only several MTB lipoproteins have been characterized to modulate this process. Here, we characterized a novel MTB lipoprotein Rv1016c, and determine its effects on host macrophages. Our results showed that Rv1016c prolonged the survival of recombinant $M$. smegmatis within host macrophages and accelerated host cell apoptosis. We present evidences that Rv1016c inhibited IFN- $\gamma$-induced antigen presentation and MHC-II expression in macrophages dependent on TLR2. We further demonstrated that Rv1016c lipoprotein inhibited IFN- $\gamma$ induced expression of CIITA IV via TLR2 and MAPK Signaling. Together, Rv1016c may involve mycobacterial virulence via a mechanism, which induced apoptosis and diminished antigen presentation to $\mathrm{CD}^{+} \mathrm{T}$ cells, contributing to immune evasion by Mycobacterium tuberculosis.

\section{MATERIALS AND METHODS}

\section{Mice and Cell Lines}

C57BL/6, TLR2 knockout, and TLR4 knockout mice were obtained from the Model Animal Research of Nanjing University (Nanjing, China), and they were housed under specific pathogenfree conditions in the Animal Center of the School of Life Science of Fudan University. All experimental procedures followed the Guidelines for the Care and Use of Laboratory Animals from the National Institutes of Health and were approved by the Animal Care and Use Ethical Committee of Shanghai Provence. THP-1 cell line was purchased from the Cell Bank of the Chinese Academy of Sciences (Shanghai, China). Cells were cultured in Dulbecco's modified Eagle's medium (DMEM) (Gibco, Grand Island, NY, USA) supplemented with 10\% fetal bovine serum (FBS), penicillin $(100 \mathrm{U} / \mathrm{ml})$ and streptomycin $(100 \mathrm{mg} / \mathrm{ml})$ and maintained at $37^{\circ} \mathrm{C}$ in a humidified incubator $\left(5 \% \mathrm{CO}_{2}\right)$. PBMCs were isolated from whole blood with FicollPaque Plus (Amersham Biosciences, Piscataway, NJ). Monocytes were prepared from PBMCs either by adherence or with the Miltenyi monocyte isolation kit (Miltenyi Biotec, Auburn, CA), and monocytes derived macrophages (MDMs) were obtained as previously described (Dao et al., 2004). The resultant 
macrophages were used during the following week. DOBW T hybridoma cells were used to detect OVA $323-339$ (Pai et al., 2003).

\section{Abs and Reagents}

Middlebrook 7H9, 7H10, and OADC were obtained from Difco (Detroit, MI). Annexin V-PE was from BD PharMingen (Mississauga, Ontario, Canada). OVA:I-Ab complexes were detected with DOBW T hybridoma cells (Pai et al., 2003). AntiHis was obtained from antibodies (Santa Cruz Biotechnology, SantaCruz, USA). Anti-Rv1016c, Anti-Rv2145c and AntiRv3425 mouse polyclonal antibody were from C57BL/6 mouse immunized by synthesized respective peptides in our lab. The primary Abs used included rabbit antiERK2, rabbit antip38, rabbit anti-JNK, rabbit anti-phosphoERK1/2, rabbit antiphospho-p38, rabbit anti-phospho-JNK, rabbit anti-phosphoI $\mathrm{B} \alpha$, and peroxidase (HRP)-conjugated secondary Abs (Cell Signaling Technology). Anti-TLR2 and anti-TLR4 were from BioLegend. Alexa488-conjugated anti- His Abs, Alexa488conjugated or Alexa555-conjugated secondary antibodies were obtained from (Cell Signaling Technology).

\section{Expression of Recombinant Rv1016c and Construction of $M$. smegmatis_Rv1016c}

The MTB gene was amplified by PCR from H37Rv genomic DNA using the forward primer 5'CCCAAGCTTGGGGAGGGC ATCCGGCGGGCTTG3' and the reverse primer $5^{\prime}$ CGGGAT CCCGGCCCCAACCGTGCGGACAAT3', which contain a Hind III site and a BamH I site, respectively. The amplified PCR product was cloned into the vector pRSFDuet-1 (Novagene, Madison, WI). The expression of the recombinant protein was induced by adding isopropyl- $\beta$-thiogalactopyranoside (IPTG) to a final concentration of $0.1 \mathrm{mM}$ as previously described ( $\mathrm{Su}$ et al., 2015). Recombinant Rv1016c was purified using a HISSelect ${ }^{\circledR}$ Nickel Affinity Gel (Sigma-Aldrich, St. Louis, MO, USA) with minor modifications. Recombinant protein was dialyzed against PBS ( $\mathrm{pH}$ 7.4) and treated with Pierce High Capacity Endotoxin Removal Resin (Pierce, USA) in accordance with the user instructions to eliminate endotoxins. The endotoxinfree Rv1016c protein was quantified with a bicinchoninic acid (BCA) protein assay kit (Pierce, Rockford, IL, USA) and frozen at $-80^{\circ} \mathrm{C}$. Samples were subjected to SDS-PAGE, and the Histagged Rv1016c protein was detected by Western blotting using mouse anti-his antibody or anti- Rv1016c.

The pNIT plasmid containing Rv1016c was electroporated into $M$. smegmatis. The selected $M$. smegmatis_Rv1016c (Ms_Rv1016c) transformants were cultured in Middlebrook 7H9 with $10 \%$ oleic albumin dextrose catalase (OADC) containing $50 \mu \mathrm{g} / \mathrm{ml}$ kanamycin. The Ms_Rv1016c strain was identified by immunoblotting using anti- Rv1016c mouse polyclonal antiserum. The vector pNIT was electroporated into M. smegmatis to generate Ms_pNIT strain as a control.

\section{Localization of the Rv1016c Protein}

MTB H37Rv and Ms_Rv1016c were grown, and subcellular fractionation of Rv1016c protein was performed as previously described ( $\mathrm{Xu}$ et al., 2015). Briefly, the cells were lysed by sonification for $30 \mathrm{~min}$, and the lysates were centrifuged at $11,000 \mathrm{~g}$ for $5 \mathrm{~min}$ at $4^{\circ} \mathrm{C}$ to precipitate cellular debris and those unlysed cells. The supernatant was subjected to ultracentrifugation at $27,000 \times \mathrm{g}$ for $40 \mathrm{~min}$ at $4^{\circ} \mathrm{C}$ to recover cell wall-associated proteins. The supernatant was dell membrane and cytosol fractions. Each fraction was subjected to Western blotting using anti-Rv1016c mouse polyclonal antibody.

Proteinase $\mathrm{K}$ degradation assay was performed as previously described (Xu et al., 2015). Briefly, the recombinant Ms_Rv1016c were treated with proteinase $\mathrm{K}$ at a concentration of $100 \mu \mathrm{g} / \mathrm{ml}$ and incubated at $37^{\circ} \mathrm{C}$ for the indicated times. The reaction was stopped by the addition of protease inhibitor Cocktail Tablets (Roche, Basel, Switzerland). Finally, each sample was analyzed by Western blotting using anti-Rv1016c and anti-Rv2145c Abs (as a cytoplasmic protein control).

\section{Intracellular Survival Assay}

THP- 1 cells $\left(1 \times 10^{6}\right.$ cells per well $)$ were cultured in 6-well tissue plates. Following $48 \mathrm{~h}$ of treatment with $0.1 \mathrm{mg} / \mathrm{ml}$ of phorbol 12-myristate-13-acetate (PMA) (Sigma), THP-1 cells were transformed into an adherent state. Cells were infected with Ms_Rv1016c or Ms_pNIT at an MOI of 10. Four hours after infection, macrophages were incubated with a final concentration of $2 \mu \mathrm{g} / \mathrm{ml}$ hygromycin for $2 \mathrm{~h}$. At indicated time after infection, macrophages were then washed twice and lysed in sterile water containing $0.025 \%(\mathrm{v} / \mathrm{v})$ SDS. The lysed cells were plated on $7 \mathrm{H} 10$ agar plates, and the colony forming units were determined as a measure of intracellular survival of recombinant M. smegmatis.

The survival of Ms_Rv1016c under different stress conditions was performed as previously described (Li et al., 2016). Briefly, the disk diffusion method was used to qualitatively measure the differences in $\mathrm{H} 2 \mathrm{O} 2$ and SDS sensitivities between Ms_Rv1016c and Ms_pNIT. The indicated amount of H2O2 and SDS was spotted on $5.5 \mathrm{~mm}$-diameter Whatman filter disks placed on the bacterial lawn. After 3-4 days incubation, the diameter of zone of complete inhibition was measured. All experiments were performed at least three times.

\section{Apoptosis Assays}

Apoptosis was assayed by either TUNEL assay or annexin VPE staining as previously described (Lopez et al., 2003). TUNEL assays were analyzed using BD PharMingen kit (Mississauga, Ontario, Canada), according to the manufacturer's instructions. Cells were considered apoptotic if they were TUNEL positive (green fluorescent nuclear staining). Cells incubated with actinomycin $\mathrm{D}$ were as positive controls. For annexin V-PE assays, cells were treated with annexin V-PE buffer $(10 \mathrm{mM}$ HEPES, pH 7.4), and then incubated for $15 \mathrm{~min}$ at room temperature in the dark. After washed, and the volume of cells was increased to $400 \mu \mathrm{l}$ with binding buffer for analysis by flow cytometry.

\section{TLR-Binding Assay}

Macrophages isolated from wild type, TLR2 ${ }^{-/-}$and TLR4 $4^{-/-}$ mouse were grown overnight on coverslips and then incubated for $30 \mathrm{~min}$ at $37^{\circ} \mathrm{C}$ with Rv1016c $(20 \mu \mathrm{g} / \mathrm{ml})$ in Hank's buffer. For flow cytometer, after washed with PBS and fixed for $15 \mathrm{~min}$ using 
$4 \%$ paraformaldehyde, the cells were stained with mouse anti-His IgG conjugated with Alexa 488 (Santa Cruz Biotechnology), then the cells were collected and 10,000 total events per sample were analyzed by using a BD FACScan calibrator (BD Biosciences, San Jose, CA). For confocal microscopy assay, macrophages were stained with anti-Rv1016 c and anti-mouse TLR2 for $2 \mathrm{~h}$ at $37^{\circ} \mathrm{C}$ in PBS containing 2\% BSA. After washing, the cells were stained with appropriate Alexa 488- or Alexa 555-conjugated secondary antibodies for $1 \mathrm{~h}$ at $37^{\circ} \mathrm{C}$, and then they were incubated with 0.1 $\mu \mathrm{g} / \mathrm{ml} \mathrm{DAPI}$ for $5 \mathrm{~min}$ at room temperature. Finally, cells were mounted on slides using Mowiol solution (Sigma-Aldrich) and observed using a 63x oil objective on an LSM 710 microscope (Carl Zeiss, Munich, Germany).

\section{Immunoprecipitation Assay}

Macrophages from WT, TLR2 ${ }^{-/-}$or $\mathrm{TLR}^{-/-}$mouse were incubated with Rv1016c $(20 \mu \mathrm{g} / \mathrm{ml})$ for $6 \mathrm{~h}$ and lysed with RIPA lysis buffer (Sangon, China). The lysates were pre-cleared by adding protein A or G sepharose beads (Santa Cruz, CA, USA) for $2 \mathrm{~h}$. After centrifugation at $10,000 \times \mathrm{g}$ for $5 \mathrm{~min}$ at $4^{\circ} \mathrm{C}$, the supernatant was incubated with Isotype IgG, anti-TLR2 or antiHis overnight at $4{ }^{\circ} \mathrm{C}$. After harvested and washed, the beads were boiled in $5 \mathrm{x}$ sample buffer for $5 \mathrm{~min}$. The proteins were separated on 10\% SDS-PAGE and probed with anti-TLR2 (BioLegend, CA, USA), or anti-His Abs (Santa Cruz, CA, USA) as indicated, followed by incubation with HRP-conjugated mouse anti-rat or rabbit anti-mouse IgG Abs. Immunoreactive bands were detected using an ECL reagent (Thermo Fisher Scientific, MA, USA) and visualized by exposure to $\mathrm{x}$-ray film.

\section{Detection of MHC-II Expression by Flow Cytometry}

MHC-II expression assay was performed as previously described (Noss et al., 2001). Macrophages $\left(2 \times 10^{6}\right.$ cells/well in a 6-well plate) were cultured for $24 \mathrm{~h}$ with $15 \mathrm{ng} / \mathrm{ml} \mathrm{IFN-} \gamma$, and then cultured for 24 or $48 \mathrm{~h}$ with IFN- $\gamma$ with or without Rv1016c protein $(20 \mu \mathrm{g} / \mathrm{ml})$. Cells were harvested by vigorous pipetting and trypsinization, incubated for $30 \mathrm{~min}$ on ice with Fc Block (BD Pharmingen) at $1 / 100$ in PBS with $0.1 \%$ BSA and for $1 \mathrm{~h}$ on ice with FITC-conjugated anti-MHC-II (e Bioscience), or isotype negative control Ig G (e Bioscience). After washed three times in PBS, cells were analyzed with a BD FACScan flow cytometer.

\section{Ag Processing and Presentation Assays}

$\mathrm{Ag}$ processing and presentation assays were performed as previously described (Noss et al., 2001). Macrophages $(5 \times$ $10^{5}$ cells/well) were incubated with increasing concentrations of Rv1016c protein or control buffer in the presence of $15 \mathrm{ng} / \mathrm{ml}$ IFN- $\gamma$ for $24 \mathrm{~h}$. Then, cells were washed and incubated with indicated concentration of $\mathrm{OVA}_{323-339}$ for $3 \mathrm{~h}$. After fixed in $1 \%$ paraformaldehyde and washed extensively, the cells were finally incubated with DOBW T hybridoma cells $\left(1 \times 10^{6} /\right.$ well for $\left.24 \mathrm{~h}\right)$. Supernatants from the Thybridoma assay were assessed for IL-2 using a CTLL-2 cell bioassay with a colorimetric determination using Alamar Blue (Alamar Biosciences, Sacramento, CA) and a Bio-Rad 550 microplate reader (Bio-Rad). Briefly, $5 \times 10^{3}$ CTLL-2 cells in $50 \mu \mathrm{l}$ of complete DMEM were incubated with
$100 \mu \mathrm{l}$ of culture supernatant for $16-20 \mathrm{~h}$. Proliferation of CTLL-2 cells in each well was measured by a colorimetric assay using Alamar blue (15 $\mu$ l; Trek Diagnostics, Westlake, $\mathrm{OH}$ ) and a Versamax tunable microplate reader. Positive and negative controls were included in each experiment to monitor CTLL-2 cell responsiveness. All data presented for Ag processing assays compared controls with experimental conditions within the same experiment, measuring the effects of lipoprotein exposure relative to macrophages exposed to control buffer. IL-2 production was expressed as OD at $550 \mathrm{~nm}$ minus OD at $595 \mathrm{~nm}$.

For IL-2 level assay, macrophages $\left(1 \times 10^{5}\right.$ cells/well $)$ from wild type, TRL2 ${ }^{-/-}$or TRL4 ${ }^{-/-}$were incubated with Rv1016c $(20 \mu \mathrm{g} / \mathrm{ml})$ or medium in the presence of IFN- $\gamma(15 \mathrm{ng} / \mathrm{ml})$ for 24 $\mathrm{h}$ at $37^{\circ} \mathrm{C}$. The cells were then washed with PBS and fixed for 20 min in in $1 \%$ paraformaldehyde. After Rv1016c antigen-specific $\mathrm{CD}^{+}{ }^{+} \mathrm{T}$ cells were isolated from mice immunized with Rv1016c proteins, $1 \times 10^{6}$ cells were co-cultured with macrophages for 48 $\mathrm{h}$ at $37^{\circ} \mathrm{C}$. Finally, the concentration of IL-2 in each supernatant sample was examined using ELISA according to manufacturer's instructions. All results of experiments represent the mean response of triplicate wells plus SD.

\section{Western Blots}

For Western blotting, equal amounts of protein were boiled in SDS-PAGE sample buffer under reducing conditions, and electrophoresed on $12 \%$ polyacrylamide gels. Protein was transferred to polyvinylidene difluoride membrane (Millipore), blocked in 5\% BSA for $1 \mathrm{~h}$ at room temperature, and incubated with primary Abs in PBS with $0.1 \%$ Tween 20 overnight at $4^{\circ} \mathrm{C}$, followed by incubation with horseradish peroxidase (HRP)conjugated secondary Abs for $1 \mathrm{~h}$ at room temperature. The primary Abs included rabbit antiERK2, rabbit anti-p38, rabbit anti-JNK, rabbit anti-phosphoERK1/2, rabbit anti-phospho-p38, rabbit anti-phospho-JNK, and rabbit anti-phospho-IкB- $\alpha$ (Cell Signalling Technology). The secondary Ab was goat anti-rabbit IgG (Cell Signalling Technology). Pierce ECL Western Blotting Substrate was used to assay target bands (Thermo Fisher Scientific, Waltham, MA).

\section{Quantitative PCR Assay of CIITA IV}

Macrophages $\left(2 \times 10^{6}\right.$ cells/well $)$ were incubated with or without Rv1016c $(20 \mu \mathrm{g} / \mathrm{ml})$, and then with IFN- $\gamma(15 \mathrm{ng} / \mathrm{ml})$ in the continued presence or absence of Rv1016c for various periods. Block of the MAPK signaling pathway experiments involved the pretreatment of THP-1 cells with inhibitors to p38 (SB203580, $10 \mu \mathrm{M})$, ERK (U0126, $10 \mu \mathrm{M})$, JNK (SP600125, $10 \mu \mathrm{M})$ for $1 \mathrm{~h}$ at $37^{\circ} \mathrm{C}$, followed by incubation with $\mathrm{Rv} 1016 \mathrm{c}$ for $36 \mathrm{~h}$ at $37^{\circ} \mathrm{C}$. Total RNA was obtained using the RNeasy kit (Qiagen) and dissolved in RNase-free water. First-strand cDNA was synthesized using the SuperScript preamplification system (Life Technologies). The quantitative real-time PCR was performed using a high-speed thermal cycler (LightCycler; Roche Diagnostics, Indianapolis, IN), and product was assayed by FastStart Master SYBR Green I (Roche Molecular Biochemicals, Indianapolis, IN). All primers were synthesized by Sangon (Shanghai, China), and their sequences were as follows: CIITA IV sense, 5' -3'ACG CTT TCT GGC TGG ATT AGT; CIITA IV 
antisense, $5^{\prime}$ - $3^{\prime}$ - TCA ACG CCA GTC TGA CGA AGG; GAPDH, sense, $5^{\prime}-3^{\prime}$ AACGACCCCTTCATTGAC, and antisense, $5^{\prime}-3^{\prime}$ TCCACGACATACTCAGCAC. RNA amount of genes were normalized to the level of GAPDH in each sample.

\section{Statistical Analysis}

All experiments were repeated 3 times at least with consistent results, which were calculated as the mean $\pm S D$ of 3 experiments. Statistical analysis was performed using a one-way ANOVA followed by Tukey's test using the origin 8.0 software (Origin Lab, USA). For all tests, $p \leq 0.05$ was considered statistically significant.

\section{RESULTS}

\section{Rv1016c is Associated with Mycobacterial Cell Wall}

To define whether Rv1016c is essential for MTB pathogenesis, the Rv1016c gene was firstly amplified from MTB H37Rv genome DNA to generate E.coli BL21_PET28_ Rv1016c strains expressed a 6x his-tagged Rv1016c protein (Figure 1A). Western blotting also confirmed that the Rv1016c protein $(\sim 24 \mathrm{kDa}$ Rv1169cHis protein) was successfully produced from E.coli BL21_PET28_ Rv1016c (Figure 1B). Secondly, the recombinant M. smegmatis strains were used to investigate the role of Rv1016c. The semiRT-PCR demonstrated that Rv1016c could only be detected in Ms_Rv1016c (Figure 1C). Western Blot analysis using the antiRv1016c antibody further confirmed only Ms_Rv1016c strain expressed Rv1016c protein in the cell lysates, while absent in Ms_pNIT strain (Figure 1D).

Finally, MTB H37Rv strain and recombinant Ms_Rv1016c were subjected to cell fractionation experiments, followed by Western blot analysis with anti-Rv1016c antibody, to determine the location of Rv1016c. The results showed that Rv1016c lipoproteins were present in the cell wall fraction, indicating that Rv1016c may be associated with the cell wall similar to the localization of Rv3425, as Rv2145c (cytoplasmic proteins) was detected only in the cytoplasm (Figure 1E). Proteinase $\mathrm{K}$ assays further confirmed the cell surface association of Rv1016c, as the Rv2145c was not degraded at all (Figure 1F).

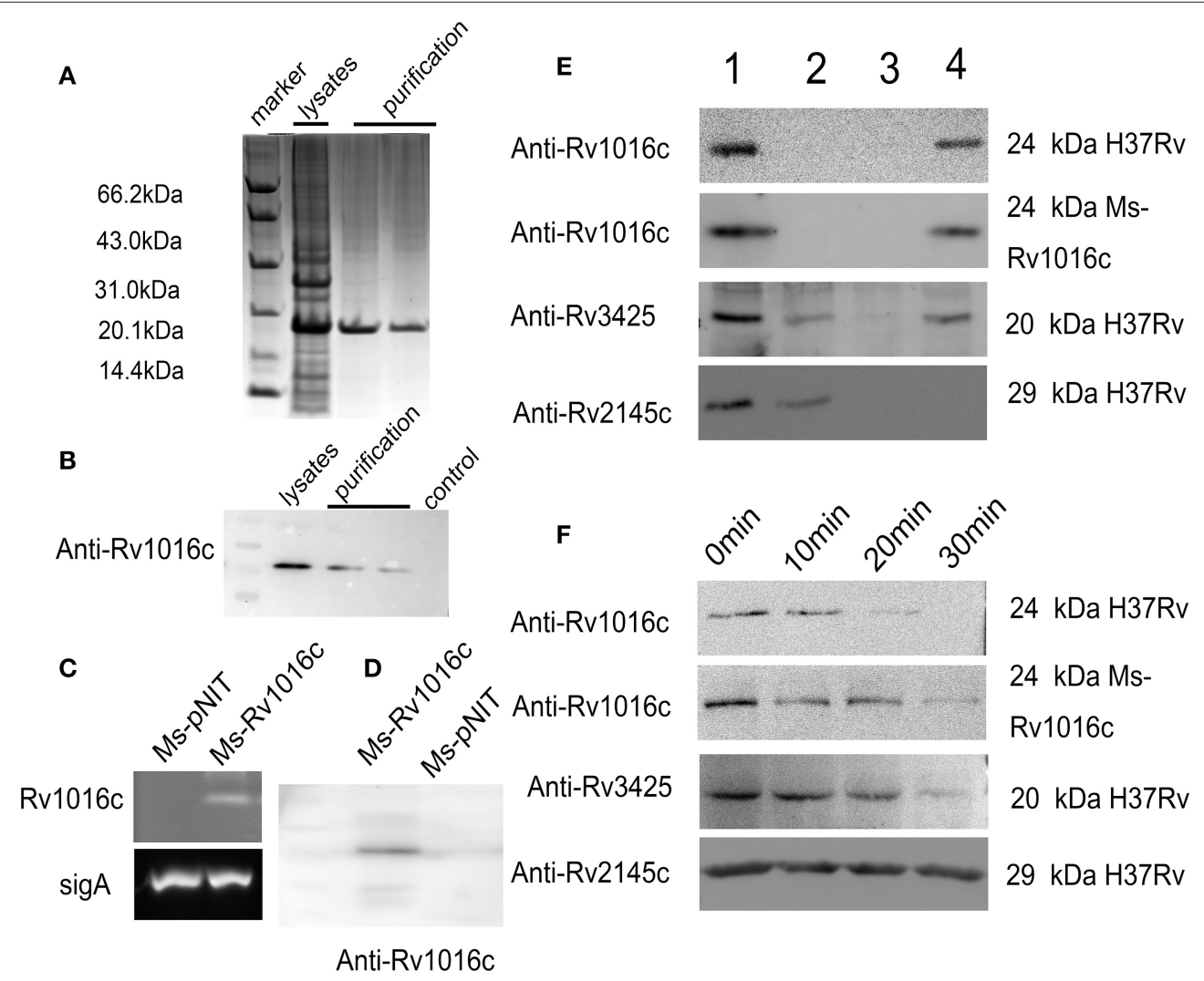

FIGURE 1 | Rv1016c is a cell Mycobacterial well-associated protein and exposes on cell surface. (A) The expression of Rv1016c-His tag in E.coli BL21 strain was detected by commassie blue staining. (B) Western analysis of solubilized and purified Rv1016c protein with anti-His Ab. (C) Detection of Rv1016c expression in recombinant M. smegmatis using RT-PCR. (D) Western blot analysis was used to examine Rv1016c expression in recombinant M. smegmatis with antiRv1016c antibody. (E) M. tuberculosis H37Rv and M. smegmatis strains expressing Rv1016c were subjected to fractionation experiments, and the Rv1016c protein in different fractions was detected by Western blotting using anti-Rv1016c antibody. The expression of cytosolic Rv2145c (cytosolic) and Rv3425 (cell wall-associated protein) were also detected by anti-Rv2145c antibody or anti-Rv3425 antibody as a negative or positive control. Lane1: whole-cell lysate; lane 2: cytoplasmic membrane fraction; lane 3: cytosolic fraction; lane 4: cell wall fraction. (F) M. tuberculosis H37Rv and Ms_Rv1016c strains expressing were digested by proteinase K for the indicated times $(0,10,20$, and $30 \mathrm{~min})$. The samples were analyzed for the expression of Rv1016c by Western blotting using anti-Rv1016c antibody. Rv2145c and Rv3425 were analyzed by Western blotting as a control. 
Taken together, these results demonstrate that Rv1016c may be a cell wall-associated lipoprotein and exposed at the cell surface.

\section{Rv1016c Enhances the Survival of the Recombinant $M$. smegmatis within Macrophages and Promotes the Resistance to Stress Factors}

To examine whether Rv1016c can modulate the intracellular mycobacterial invasion, growth and survival, we compared the growth rate of Ms_Rv1016c and Ms_pNIT in macrophages. The infection experiment was carried out at an MOI of 10 (10 bacterium per 1 macrophages). Our results demonstrated that macrophages infected with Ms_pNIT and Ms_Rv1016c show the same invasion ratio (Figure $\mathbf{2 A}$ ), and there was no significant difference in growth rates of the two strains (Figure 2B). However, Ms_Rv1016c showed significantly higher bacillary counts in THP-1 cells 24-72 h after infection (Figure 2C). The results demonstrate that the presence of Rv1016c does not influence uptake but can enhance the intracellular survival of $M$. smegmatis within macrophages.

To further determine how Rv1195 enhanced the intracellular survival in macrophages, we compared the survival rate of the Ms_pNIT and Ms_Rv1016c under stresses in vitro. As shown in Figure 2D, the survival percentage of Ms_Rv1016c was significantly higher than Ms_pNIT under acid stress $(\mathrm{pH}=3)$. For reactive oxygen resistance assay, the square of the zone was smaller in Ms_Rv1016c than those of the Ms_pNIT after $\mathrm{H}_{2} \mathrm{O}_{2}$ treatment (Figure 2E). Moreover, the percentage of survival of Ms_Rv1016c was significantly higher than that of Ms_pNIT after SDS treatment (Figure 2F). These findings indicate that Rv1016c may be involved in virulence, leading to increased resistance to stresses during mycobacteria infection.

\section{Rv1016c is a Ligand for TLR2}

Although recognition of mycobacterial lipoproteins such as Lpq H, Lpr G, and Lpr A are known to signal through TLR, Rv1016c has not been tested for TLR ligand activity. To analyze whether Rv1016c can bind to TLR2, macrophages from WT, TLR2 $2^{-/-}$and TLR $4^{-/-}$mice were incubated for $24 \mathrm{~h}$ with Rv1016c. Cells were then stained with mouse anti-His IgG conjugated with Alexa 488. Flow cytometry analysis showed that Rv1016c bound to the surface of WT and TLR4 ${ }^{-/-}$mouse macrophages but not to the surface of TLR2 ${ }^{-/-}$cells (Figures $3 \mathbf{A}, \mathbf{B}$ ). Immunofluorescence analysis also showed strong fluorescence of anti-Rv1016c on the surface of $\mathrm{WT}$, and TLR4 ${ }^{-/}$mice cells exposed to Rv1016c but no fluorescence on the surface of TLR2 ${ }^{-/-}$ macrophages cells (Figure 3C). To further ascertain whether Rv1016c physically binds to the TLR2 molecule, we conducted an immunoprecipitation assay using whole-cell extracts from THP-1 cells. Western blots probed with anti-TLR2 showed that Rv1016c was able to interact with TLR2. No band was visible in the beads alone group or Rv1016c alone group (Figure 3D). These results demonstrate that Rv1016c interacts specifically and predominantly with TLR2.
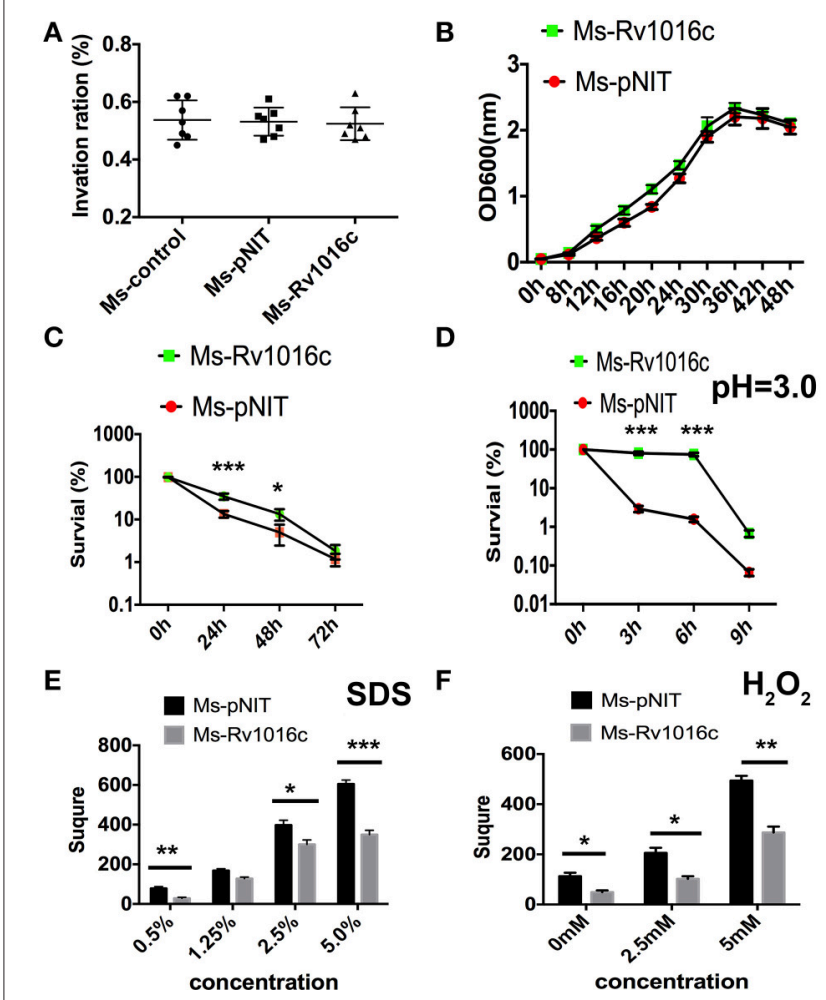

FIGURE 2 | Rv1016c promotes intracellular survival of $M$. smegmatis and boost the recombinants resistance to stress factors within macrophages. (A) THP-1 cells were infected with Ms_pNIT or Ms_Rv1016c at an $\mathrm{MOI}$ of 10 at day 0 ( $4 \mathrm{~h}$ post-infection). Invasion ratio is the ratio of the number of intracellular bacteria and the number of initial infection bacteria. (B) Growth of Ms_Rv1195 and Ms_pNIT strains at $37^{\circ} \mathrm{C}$ in $7 \mathrm{H} 9$ liquid medium were assayed by OD600 value in every $4 \mathrm{~h}$. (C) THP-1 cells were infected with Ms_pNIT or Ms_Rv1016c at the MOI of 10. After infection, Lysates containing the live bacteria were diluted gradually and then plated on $7 \mathrm{H} 10$ agar plates to determine bacteria number. (D) Growth of Ms_pNIT or Ms_Rv1016c under Low pH $(\mathrm{pH}=3)$ was measured in vitro. The bacteria were collected by centrifugation and resuspended to an OD600 of $0.8 \mathrm{in} 20 \mathrm{ml} 7 \mathrm{H} 9$. The cultures were incubated at $37^{\circ} \mathrm{C}$ and $0.1 \mathrm{ml}$ removed for viable count enumeration. (E,F) Growth of Ms_pNIT or Ms_Rv1016c under stress conditions. Disk diffusion method was used to measure the survival of recombinant Ms_Rv1016c when exposure to SDS (E) and H2O2 (F). All results were generated from three independent experiments and Data are shown as Means \pm SD of triplicate wells. $\left({ }^{\star} p<0.05,{ }^{* *} p<0.01\right.$, ${ }^{\star * *} p<0.001$, determined by Student's $t$-test).

\section{Rv1016c Induces Macrophages Apoptosis through TLR2}

To detect whether Rv1016c induces macrophages apoptosis, THP-1 cells or monocytes derived macrophages (MDMs) were treated with a range of concentrations of recombinant Rv1016c. Apoptosis was determined by flow cytometric analysis of annexin V-PE binding or by TUNEL assay. As shown in Figure 4A, increased levels of apoptosis were apparent with

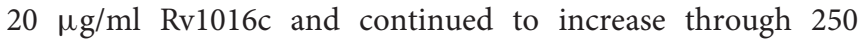
$\mu \mathrm{g} / \mathrm{ml}$, indicating that Rv1016c significantly induced apoptosis both in THP-1 cells and MDMs in a dose dependent manner. Apoptosis kinetics analysis showed that $20 \mu \mathrm{g} / \mathrm{ml} \mathrm{Rv1016 \textrm {c }}$ significantly induced apoptosis as early as $1 \mathrm{~h}$ after exposure and 


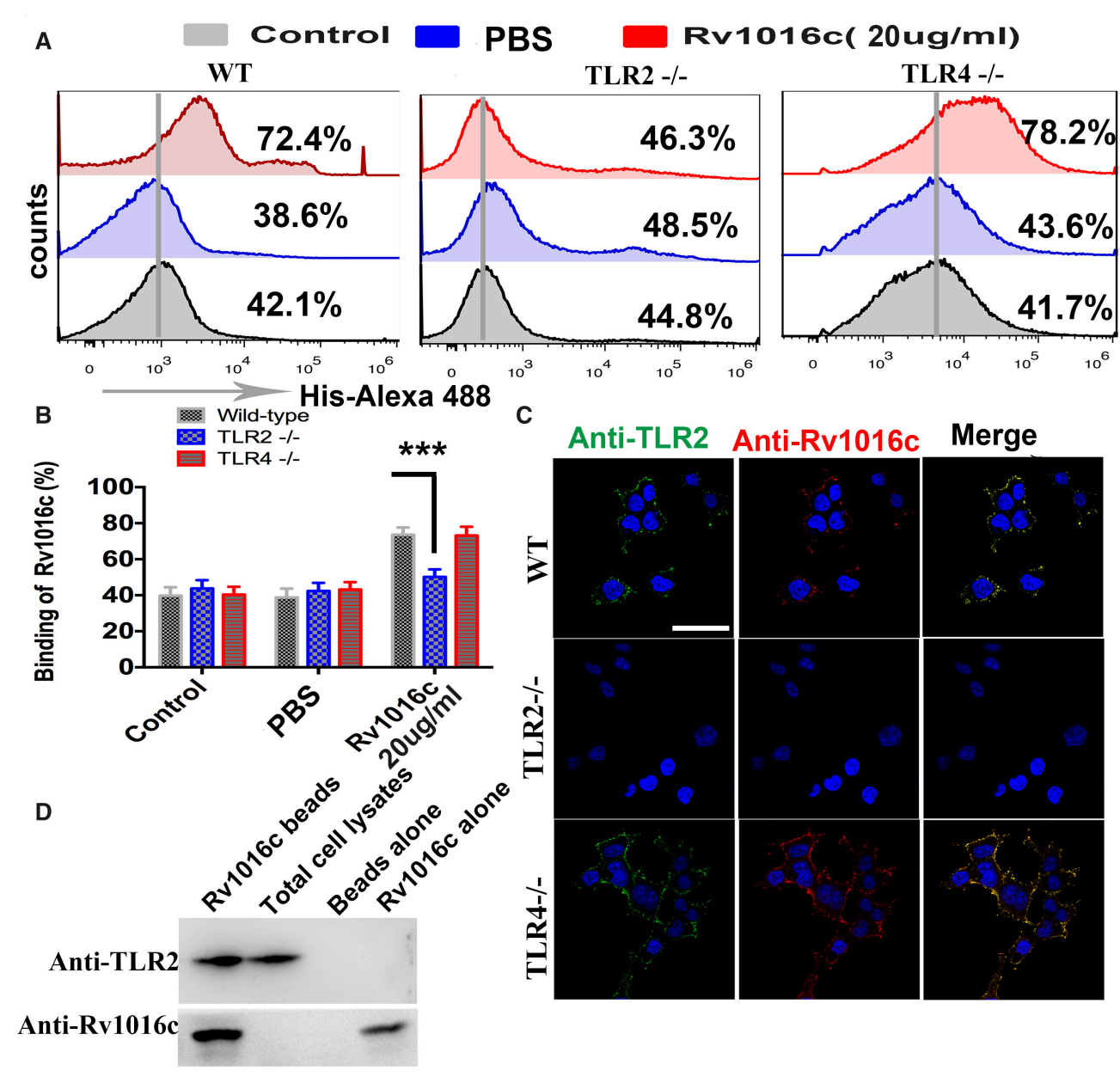

FIGURE 3 | Rv1016c interacts with TLR2, but not with TLR4. (A,B) Macrophages derived from WT, TLR2 ${ }^{-/-}$, and TLR4-/- mice were incubated with Rv1016c-His (20 $\mathrm{g} / \mathrm{ml})$ for $1 \mathrm{~h}$, followed by incubation with Alexa488-conjugated anti-His Abs. After washing and staining, flow cytometry was used to examine the binding between Rv1016c and TLR2. (C) Macrophages derived from WT, TLR2 ${ }^{-/-}$, and TLR4 $-/-$mice were treated with Rv1016c (20 $\left.\mu \mathrm{g} / \mathrm{ml}\right)$ for $1 \mathrm{~h}$, fixed and stained with primary antibodies (mouse anti-Rv1016c, rat anti-mouse TLR2), followed by incubation with appropriate Alexa488- or Alexa555-conjugated secondary antibodies. Cells were photographed under fluorescence microscopy (original magnification $\times 63$ ). Scale bar $=10 \mu \mathrm{m}$ (D) Cells were incubated with Rv1016c immobilized on Ni-NTA beads for $6 \mathrm{~h}$, and proteins were visualized by Western blotting with anti-His or anti-TLR2 Abs to assay the presence of TLR2 with bead bound proteins. All data were generated from three independent experiments and Data are shown as Means \pm SD of triplicate wells. ${ }^{\star \star \star} p<0.001$, determined by Student's t-test).

continued to increase through $24 \mathrm{~h}$ (Figure 4B). Recombinant Rv1016c-induced apoptosis was specific, as the frequency of annexin V-PE-positive cells after treatment with the Histagged $\beta$-galactosidase was similar to that observed for untreated control cells (Figure 4C). In addition, to exclude whether LPS contamination leads to apoptosis, the recombinant Rv1016c protein was exposed to either heat treatment or to polymyxin $\mathrm{B}$ before addition to cells. As shown in Figure 4D, LPS- induced apoptosis changed little due to its resistant to heat treatment not its sensitive to polymyxin B. In contrast, the apoptotic effects of recombinant Rv1016c protein were completely abrogated after heat treatment. We further determined the role of TLR2 in Rv1016c-induced apoptosis. THP-1 cells were incubated with Isotype IgG, anti-TLR2 Abs or anti-TLR4 Abs for 18 $\mathrm{h}$ before Rv1016c treatment, and apoptosis was analyzed as previously described. As shown in Figure 4E, incubation with anti-TLR2 Abs significantly abrogated the proapoptotic effects of Rv1016c lipoprotein. Similarly, when compared with wild type or TLR4 knockout cells, apoptosis induced by Rv1016c was completely abrogated in TLR2 knockout cells (Figure 4F). Taken together, these results indicate that Rv1016c-induced apoptosis is dependent on TLR- 2 .

\section{Rv1016c is Able to Inhibit IFN- $\gamma$-Induced Expression of MHC-II in Macrophages}

Prolonged incubation of macrophages with mycobacterial lipoproteins modulates IFN- $\gamma$-induced MHC-II expression and antigen-presentation activity (Pennini et al., 2006). To clarify whether the Rv1016c lipoprotein regulates MHC-II expression, IFN- $\gamma$-stimulated THP-1 cells were treated with or without 


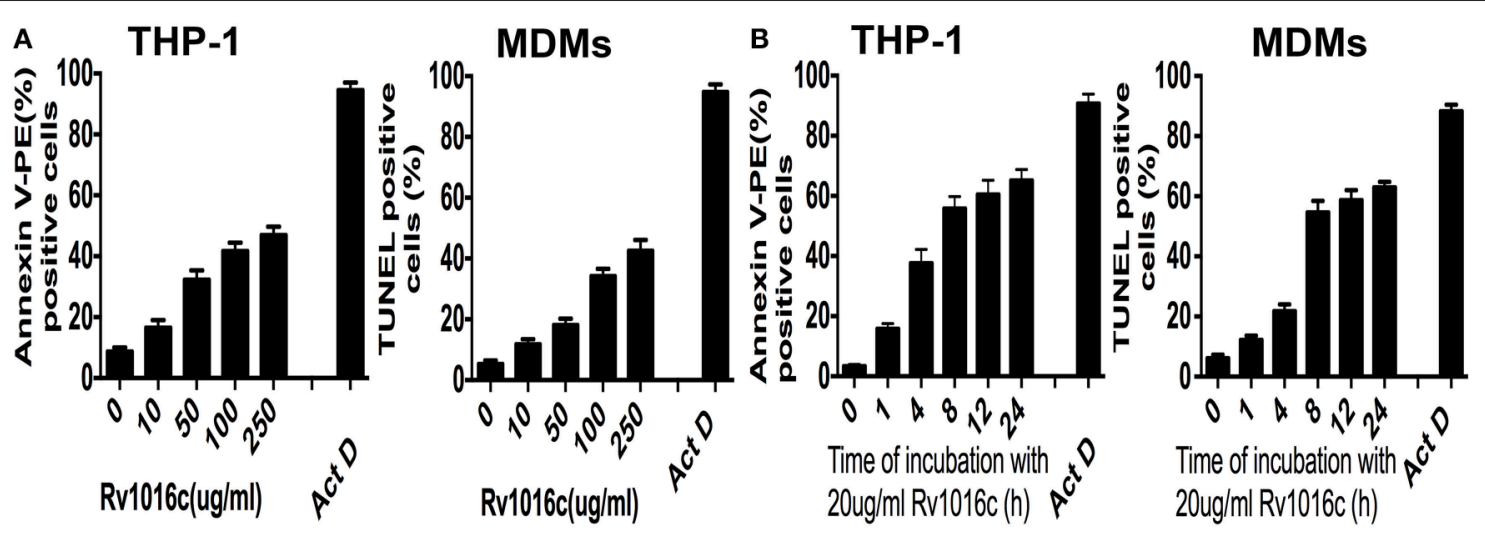

C THP-1

D THP-1
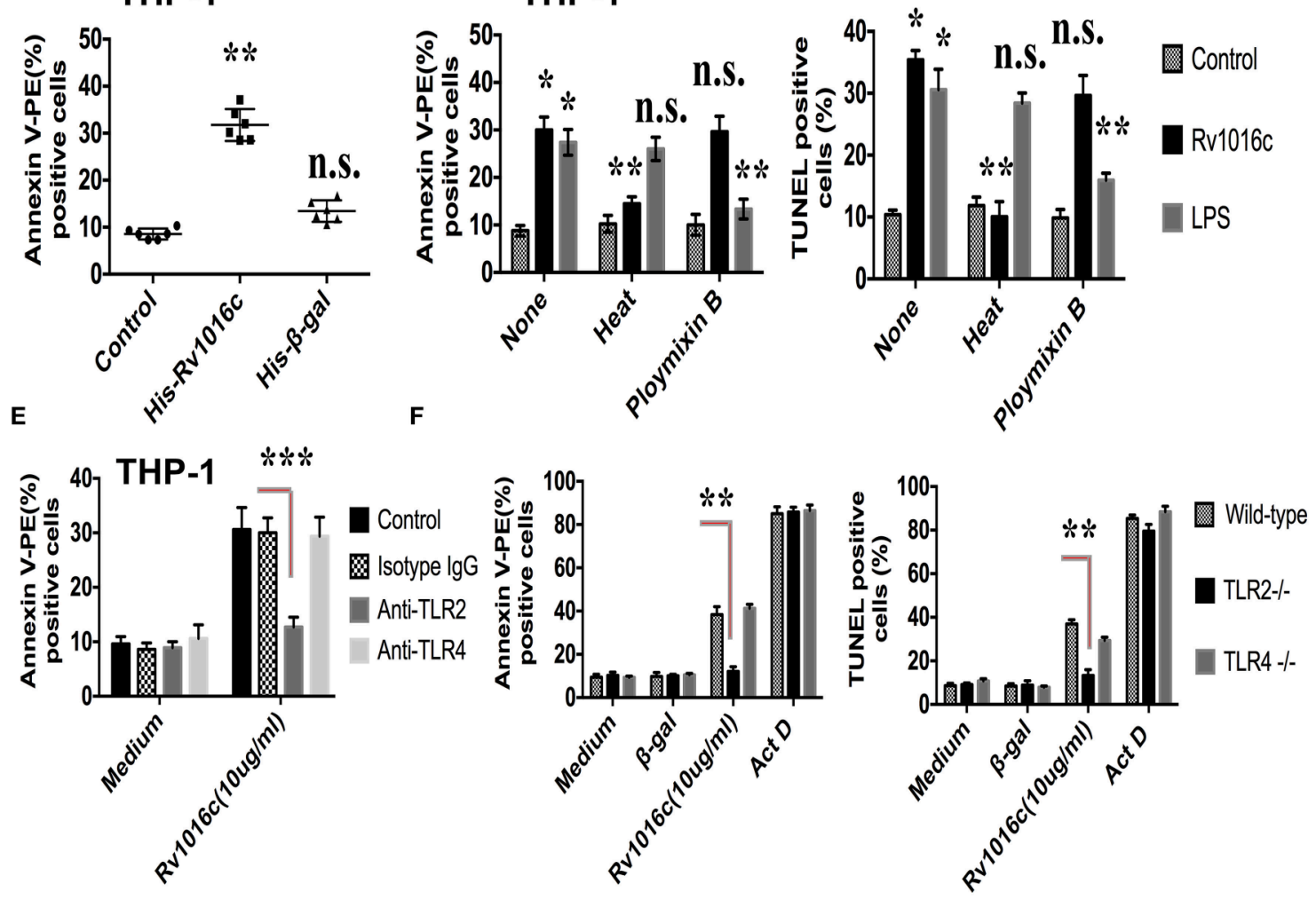

FIGURE 4 | Rv1016c induces apoptosis through TLR2 in macrophages. THP-1 cells or monocytes derived macrophages (MDMs) were incubated with either a range of concentrations of Rv1016c for $2 \mathrm{~h} \mathrm{(A)} \mathrm{or} \mathrm{for} \mathrm{varying} \mathrm{lengths} \mathrm{of} \mathrm{time} \mathrm{with} 20 \mu \mathrm{g} / \mathrm{ml}$ recombinant protein (B). Apoptosis was analyzed by flow cytometry or TUNEL assay. Actinomycin D was used as a positive control for apoptosis. (C) Apoptosis induced by Rv1016c is not due to His tag. THP-1 cells were incubated with equal amounts of His-tagged $\beta$-galactosidase (as control for specificity) or His-tagged Rv1016c. Apoptosis was analyzed by flow cytometry. (D) Apoptosis induced by Rv1016c is not due to LPS contamination. THP-1 cells were incubated with recombinant Rv1016c or LPS. Before addition to cells (20 $\mu \mathrm{g} / \mathrm{ml}$ for $2 \mathrm{~h}$ ), His-tagged Rv1016c was either subjected to boiling for $1 \mathrm{~h}$ or treated with polymyxin B resin. For the latter, $100 \mu$ l of polymyxin bead slurry was added to $100 \mu \mathrm{l}$ of recombinant Rv1016c preparation and incubated at $4^{\circ} \mathrm{C}$ for $1 \mathrm{~h}$. After centrifugation, the supernatant was used for apoptosis induction analyzed by flow cytometry or TUNEL assay. (E) THP-1 cells were incubated with Isotype lg G (30 $\mu \mathrm{g} / \mathrm{ml})$, Anti-TLR2 blocking Abs (30 $\mu \mathrm{g} / \mathrm{ml})$ or Anti-TLR4 blocking Abs (30 $\mu \mathrm{g} / \mathrm{ml})$ for $18 \mathrm{~h}$, followed by treated with $20 \mu \mathrm{g} / \mathrm{ml}$ recombinant Rv1016c for $2 \mathrm{~h}$. Apoptosis was analyzed by flow cytometry. (F) Macrophages derived from C57BL/6, TLR2 ${ }^{-/-}$, and TLR4-/mice were incubated with Rv1016c-His $(20 \mu \mathrm{g} / \mathrm{ml})$ for $2 \mathrm{~h}$, and then apoptosis was analyzed flow cytometry or TUNEL assay. Incubation of cells with actinomycin D or Histagged $\beta$-galactosidase was used as a control for apoptosis. All data were generated from three independent experiments and Data are shown as Means \pm SD of triplicate wells. $\left({ }^{\star} p<0.05,{ }^{\star \star} p<0.01,{ }^{\star \star *} p<0.001\right.$ vs. corresponding controls).

Rv1016c for 24-48 h, and then flow cytometry was used to analyze MHC-II expression. As shown in Figure 5A, the level of MHC-II was low in Rv1016c-pusled macrophages compared to cells cultured in medium, indicating that Rv1016c lipoprotein inhibited IFN- $\gamma$-enhanced MHC-II expression. Similar observations were also made for the endogenous MHC 


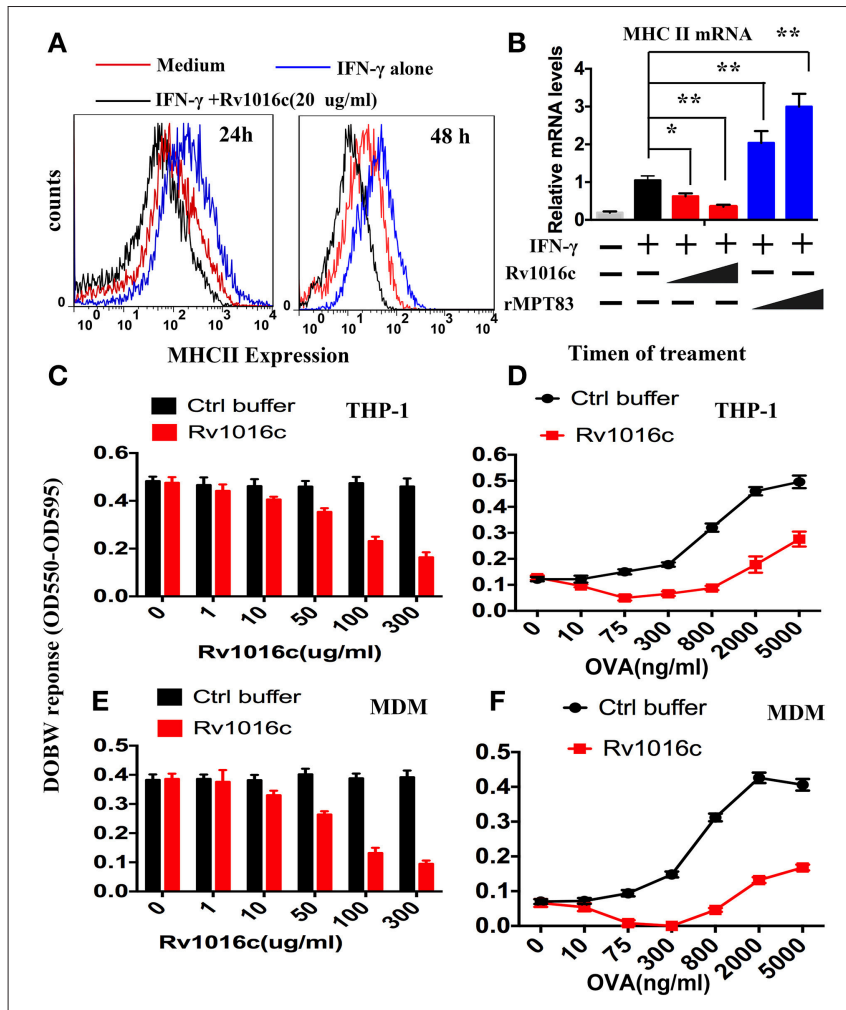

FIGURE 5 | Rv1016c inhibits IFN- $\gamma$-induced MHC-Il expression and Ag processing. (A) THP-1 cells were stimulated with IFN- $\gamma(15 \mathrm{ng} / \mathrm{ml})$ for $24 \mathrm{~h}$ at $37^{\circ} \mathrm{C}$, and then treated with or without Rv1016c-His $(20 \mu \mathrm{g} / \mathrm{ml})$ for 24 (left) or $48 \mathrm{~h}$ (right). Cells were incubated with FITC-conjugated anti-MHC II, or isotype Ig G control Abs for 30 min in the dark room. MHC-II expression was analyzed with a BD FACScan flow cytometer. (B) THP-1 cells were incubated with medium, Rv1016c (20 $\mu \mathrm{g} / \mathrm{ml}, 50 \mu \mathrm{g} / \mathrm{ml})$ or rMPT8 $(20 \mu \mathrm{g} / \mathrm{ml}, 50 \mu \mathrm{g} / \mathrm{ml}$, as a positive control) in the presence of with IFN- $\gamma(15 \mathrm{ng} / \mathrm{ml})$. MHC II mRNA levels were measured by GPCR. (C) THP- $1\left(1 \times 10^{6}\right.$ cells /well) were incubated with increasing concentrations of Rv1016c or control buffer for $24 \mathrm{~h}$ in the presence of IFN- $\gamma(15 \mathrm{ng} / \mathrm{ml})$. Then, cells were washed and incubated with $\mathrm{OVA}_{323}-339$ $(800 \mathrm{ng} / \mathrm{ml})$ for $3 \mathrm{~h}$. After fixed in 1\% paraformaldehyde and washed extensively, the cells were finally incubated with DOBW T hybridoma cells $(1 \times$ $10^{6}$ /well for $24 \mathrm{~h}$ ). Supernatants from the T hybridoma assay were assessed for IL-2 using a CTLL-2 cell bioassay. (D) THP-1 cells were incubated with $100 \mu \mathrm{g} / \mathrm{ml}$ Rv $1016 \mathrm{c}$ in the presence of IFN- $\gamma(15 \mathrm{ng} / \mathrm{ml})$, After $24 \mathrm{~h}$ incubation, cells were pulsed with increasing concentrations of $\mathrm{OVA}_{323-339}$ for $3 \mathrm{~h}$. Ag processing was measured with DOBW T hybridoma cells as previously described. (E) HLA-DR1-positive MDMs were treated with increasing concentrations of Rv1016c or control buffer for $24 \mathrm{~h}$. Following incubation with Rv1016c, macrophages were pulsed with OVA $323-339(800 \mathrm{ng} / \mathrm{ml})$ for $3 \mathrm{~h}$. Ag processing was measured with DOBW T hybridoma cells as previously described. (F) HLA-DR1-positive MDMs were incubated with $100 \mu \mathrm{g} / \mathrm{ml}$ Rv1016c in the presence of IFN- $\gamma(15 \mathrm{ng} / \mathrm{ml})$, After $24 \mathrm{~h}$ incubation cells were pulsed with indicated concentration of $\mathrm{OVA}_{323}-339$ for $3 \mathrm{~h}$ and fixed. $\mathrm{Ag}$ processing was measured with DOBW T hybridoma cells as previously described. Data points represent the mean of triplicate samples with SD and each panel is representative of at least two independent experiments. $\left({ }^{*} p<0.05,{ }^{* *} p<0.01\right.$ vs. corresponding controls).

II mRNA levels in THP-1 cells (Figure 5B). To further assess whether Rv1016c affects the ability of Ag processing and presentation of mouse macrophages, THP-1 cells or monocytederived macrophages (MDMs) were incubated for $24 \mathrm{~h}$ with or

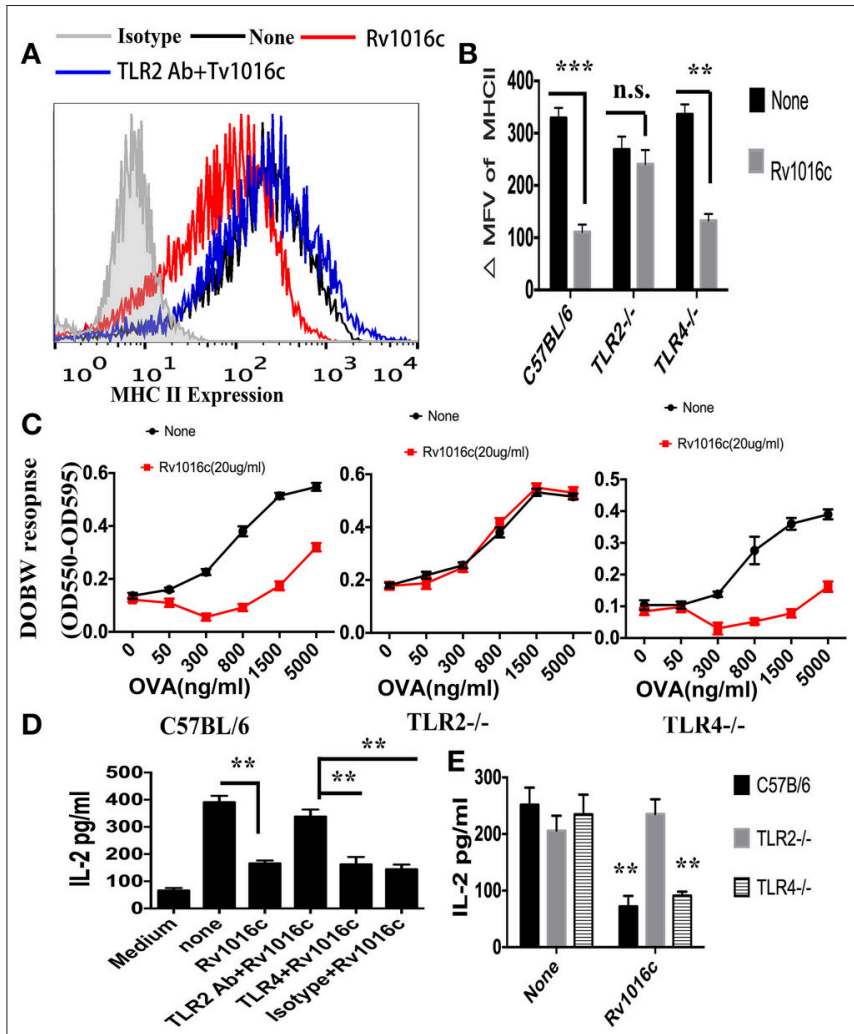

FIGURE 6 | Inhibition of MHC-II expression and Ag processing by Rv1016c lipoprotein is dependent on TLR 2. (A) THP-1 were pretreated with Isotype lg G (30 $\mu \mathrm{g} / \mathrm{ml})$ or Anti-TLR2 blocking Abs $(30 \mu \mathrm{g} / \mathrm{ml})$ for $18 \mathrm{~h}$, followed by treated with IFN- $\gamma(15 \mathrm{ng} / \mathrm{ml})$ for $24 \mathrm{~h}$ at $37^{\circ} \mathrm{C}$, and then treated with or without Rv1016c-His $(20 \mu \mathrm{g} / \mathrm{ml})$ for $24 \mathrm{~h}$. Cells were then incubated with FITC-conjugated anti-MHC II or isotype Ig G control Abs for 30 min in the dark room. MHC-II expression was washed and analyzed with a BD FACScan flow cytometer. (B) Macrophages from WT, TLR2 ${ }^{-/-}$or TLR4 ${ }^{-/-}$ mice were stimulated with IFN- $\gamma(15 \mathrm{ng} / \mathrm{ml})$ for $24 \mathrm{~h}$ at $37^{\circ} \mathrm{C}$, and then treated with or without Rv1016c-His $(20 \mu \mathrm{g} / \mathrm{ml})$ for $24 \mathrm{~h}$. MHC-II expression was measured as previously described. $\triangle$ MFV was calculated as the MFV of cells stained with anti-MHC-II minus the MFV of cells stained with the isotype-control Ab. (C) Macrophages from WT, TLR2 ${ }^{-/-}$or TLR4 ${ }^{-/-}$mice were stimulated with IFN- $\gamma(15 \mathrm{ng} / \mathrm{ml})$ for $24 \mathrm{~h}$ at $37^{\circ} \mathrm{C}$, and then treated with or without Rv1016c-His $(20 \mu \mathrm{g} / \mathrm{ml})$ for $24 \mathrm{~h}$. Then, cells were washed and incubated with indicated concentration of $\mathrm{OVA}_{323-339}$ for $6 \mathrm{~h}$. After fixed in $1 \%$ paraformaldehyde and washed extensively, the cells were finally incubated with DOBW T hybridoma cells for $24 \mathrm{~h}$. Supernatants from the T hybridoma assay were assessed for IL-2 using a CTLL-2 cell bioassay. (D) THP-1 cells $\left(1 \times 10^{5}\right.$ cells/well) were pretreated with Isotype lg G (30 $\left.\mu \mathrm{g} / \mathrm{ml}\right)$, Anti-TLR2 blocking Abs $(30 \mu \mathrm{g} / \mathrm{ml})$ or Anti-TLR4 blocking Abs $(30 \mu \mathrm{g} / \mathrm{ml})$ for $18 \mathrm{~h}$, and then incubated with or without Rv1016c $(20 \mu \mathrm{g} / \mathrm{ml})$ in the presence of IFN- $\gamma$ $(15 \mathrm{ng} / \mathrm{ml})$ for $24 \mathrm{~h}$ at $37^{\circ} \mathrm{C}$. After washed with PBS and fixed in $1 \%$ paraformaldehyde, Rv1016c Ag-specific CD4 ${ }^{+} \mathrm{T}$ cells $\left(1 \times 10^{6} \mathrm{cells} /\right.$ well $)$ were added to the plates, and were co-cultured for $48 \mathrm{~h}$ at $37^{\circ} \mathrm{C}$. ELISA was used to assay the level of IL-2 in supernatant. (E) Macrophages

$\left(1 \times 10^{5} \mathrm{cells} /\right.$ well) from wild type, TRL2 ${ }^{-/-}$or TRL4 $4^{-/}$mice were incubated with Rv1016c (20 $\mu \mathrm{g} / \mathrm{ml})$ or medium in the presence of IFN- $\gamma$ (15 $\mathrm{ng} / \mathrm{ml}$ ) for $24 \mathrm{~h}$ at $37^{\circ} \mathrm{C}$. Cells were washed with PBS and fixed for $20 \mathrm{~min}$ in $1 \%$ paraformaldehyde. Then, $1 \times 10^{6}$ cells/well Rv1016c antigen-specific $\mathrm{CD}^{+}{ }^{+} \mathrm{T}$ cells were co-cultured with macrophages for $48 \mathrm{~h}$ at $37^{\circ} \mathrm{C}$. IL-2 level was assayed as previously described. All data were generated from three independent experiments and Data are shown as Means \pm SD of triplicate wells. ( ${ }^{\star *} p<0.01,{ }^{\star * \star} p<0.001$ vs. corresponding controls). 
without Rv1016c, exposed to $\mathrm{OVA}_{323-339}$ for $3 \mathrm{~h}$, fixed, and incubated with DOBW T hybridoma cells for $24 \mathrm{~h}$. IL-2 secretion was determined using a CTLL-2 assay. The results showed that exposure of macrophages to increasing concentrations of Rv1016c for $24 \mathrm{~h}$ inhibited MHC-II Ag processing of $\mathrm{OVA}_{323-339}$ (Figures 5C,E). Kinetic analysis demonstrated that substantial inhibition was first noted at $300 \mathrm{ng} / \mathrm{ml}$ with almost complete inhibition by $2000 \mathrm{ng} / \mathrm{ml} \mathrm{OVA}_{323-339}$ (Figures 5D,F). These findings may identify Rv1016c as an inhibitor of MHC-II expression and Ag processing.

\section{Rv1016c Inhibits MHC-II Ag Processing Dependent on TLR-2}

To examine whether Rv1016c inhibits MHC-II Ag processing through TLR2, THP-1 cells were pretreated with Isotype Ig G $(30 \mu \mathrm{g} / \mathrm{ml})$ or Anti-TLR2 blocking Abs $(30 \mu \mathrm{g} / \mathrm{ml})$ for $18 \mathrm{~h}$, followed by treated with IFN- $\gamma(15 \mathrm{ng} / \mathrm{ml})$ for 24 $\mathrm{h}$ at $37^{\circ} \mathrm{C}$, and then treated with or without Rv1016c-His $(20 \mu \mathrm{g} / \mathrm{ml}$ ) for $24 \mathrm{~h}$, flow cytometry was finally used to analyze. As shown in Figure 6A, Rv1016c-mediated inhibition of IFN- $\gamma$-induced MHC-II expression was reversed in those macrophages, which were incubated with blocking anti-TLR2 Abs. Additionally, Rv1016c lipoprotein decreased expression of MHC-II by C57BL/6 and TLR4 ${ }^{-/}$mice but not TLR2 ${ }^{-/-}$ mice (Figure 6B). To further assess whether Rv1016c affects the ability of Ag processing and presentation via TLR2, macrophages from wild type, TLR2 ${ }^{-/-}$or TLR $4^{-/-}$mouse were incubated for $24 \mathrm{~h}$ with or without $\operatorname{Rv} 1016 \mathrm{c}(20 \mu \mathrm{g} / \mathrm{ml})$, exposed to a range concentration of $\mathrm{OVA}_{323-339}$ for $3 \mathrm{~h}$, fixed, and incubated with DOBW T hybridoma cells. IL-2 secretion was determined using a CTLL-2 assay. Inhibition of MHC-II Ag processing of $\mathrm{OVA}_{323-339}$ was reserved in TLR2 ${ }^{-/-}$mouse macrophages (Figure 6C). Furthermore, THP-1 cells were pretreated with Isotype Ig G, Anti-TLR2 blocking Abs or Anti-TLR4 blocking Abs for $18 \mathrm{~h}$, followed by treated with or without Rv1016c $(20 \mu \mathrm{g} / \mathrm{ml})$ for $24 \mathrm{~h}$ in the presence of IFN- $\gamma(15 \mathrm{ng} / \mathrm{ml})$, and then incubated with Rv1016c-specific splenic $\mathrm{CD}^{+} \mathrm{T}$ cells. Supernatant levels of IL-2 were measured using ELISA. The result showed that Rv1016c-induced decrease in MHCII presentation of Rv1016c peptide was blocked by anti-TLR2 Abs but not by anti-TLR4 or the isotype Abs, as reflected by increased IL-2 levels (Figure 6D). Similarly, Rv1016c inhibited the processing and presentation of Rv1016c peptide by C57BL/6 and TLR4 ${ }^{-/-}$macrophages but not TLR $2^{-/-}$macrophages (Figure 6D). These findings indicate that Rv1016c lipoprotein may inhibit expression of MHC-II molecules and the processing of $\mathrm{Ag}$ for presentation to $\mathrm{CD} 4^{+}$cells dependent on TLR2, independent on TLR4.

\section{Rv1016c Inhibits IFN- $\gamma$-Induced CIITA Expression by TLR2 and MAPK Signaling}

As an essential IFN- $\gamma$-associated immuneregulator, class II transactivator (CIITA) IV regulates MHC II expression. Previous study demonstrated that $19-\mathrm{kDa}$ lipoprotein inhibited the expression of CIITA induced by IFN- $\gamma$. To determine whether Rv1016c has similar effects on CIITA IV, we incubated macrophages with Rv1016c for $18 \mathrm{~h}$, and then treated the cells with IFN- $\gamma$ for the indicated time. As shown in Figure 7A, CIITA expression induced by IFN- $\gamma$ was inhibited by Rv1016c treatment. In addition, we used macrophages from C57BL/6, TLR $2^{-/-}$or TLR $4^{-/-}$mice to examine whether inhibition of CIITA IV requires TLR2 signaling through. Q-PCR results showed that the ability of Rv1016c to inhibit IFN- $\gamma$-induced CIITA expression was abrogated in TLR2 $2^{-/-}$macrophages (Figure 7B).

MAPK signaling is the key mediators of TLR2 pathway. In this context, MAPK was activated by Rv1016c incubation, as reflected by the increased phosphorylation of p38, ERK, and JNK (Figure 7C). To further determine whether MAPK plays a key role in Rv1016c-mediated inhibition of CIITA expression, we treated macrophages with p38 inhibitor

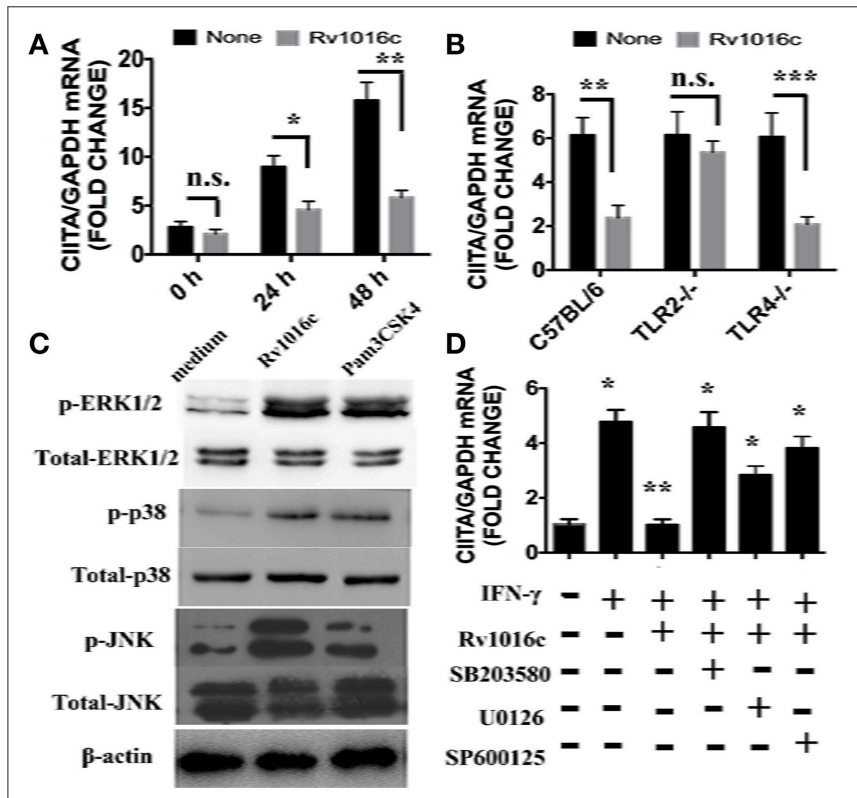

FIGURE 7 | Rv1016c inhibits IFN- $\gamma$ - induced expression of CIITA dependent on TLR2 and MAPK pathway. (A) THP-1 cells were incubated with or without Rv1016c-His $(20 \mu \mathrm{g} / \mathrm{ml})$ for $24 \mathrm{~h}$, then with IFN- $\gamma(15 \mathrm{ng} / \mathrm{ml})$ in the continued presence or absence of Rv1016c for the indicated times. RNA was isolated, and quantitative real-time PCR was used to analyze the expression of CIITA. (B) Macrophages $\left(1 \times 10^{6} \mathrm{cells} /\right.$ well $)$ from wild type, TRL2 ${ }^{-/-}$or TRL4 ${ }^{-/-}$were incubated with or without Rv1016c-His $(20 \mu \mathrm{g} / \mathrm{ml})$ for $24 \mathrm{~h}$, then with IFN- $\gamma(15 \mathrm{ng} / \mathrm{ml})$ in the continued presence or absence of Rv1016c-His for the indicated times. The expression of CIITA was measured as previously described. (C) Rv1016c activates MAPKs pathway in macrophages. THP-1 cells were treated with Rv1016c $(20 \mu \mathrm{g} / \mathrm{ml})$ or Pam3CSK4 $(5 \mu \mathrm{g} / \mathrm{ml})$ for $1 \mathrm{~h}$, the phosphorylation of p38, ERK (1/2) and JNK were examined by blotting with specific antibodies to p-p38, p38, p-ERK1/2, ERK1/2, p-JNK, and JNK. (D) Rv1016c-mediated inhibition of CIITA expression is dependent on MAPK signaling. Macrophages were incubated with or without DMSO (vehicle control), p38 (SB203580, $10 \mu \mathrm{M})$, ERK (U0126, $10 \mu \mathrm{M})$, or JNK (SP600125, $10 \mu \mathrm{M})$ for $1 \mathrm{~h}$ at $37^{\circ} \mathrm{C}$. Rv1016c $(20 \mu \mathrm{g} / \mathrm{ml})$ was added to samples for the next $6 \mathrm{~h}$, and IFN- $\gamma(15 \mathrm{ng} / \mathrm{ml})$ was added for a final $5 \mathrm{~h}$ (presence of inhibitors maintained). Expression of CIITA mRNA was assayed as previously described. All samples were first normalized to GAPDH and are expressed as the fold change compared with untreated controls. All data are expressed as the mean \pm SD from three separate experiments. ( ${ }^{\star} p<0.05,{ }^{* *} p<0.01,{ }^{\star * \star} p<0.001$ vs. corresponding controls). 
(SB203580), ERK1/2 inhibitor (U0126), JNK inhibitor (SP600125) for $1 \mathrm{~h}$ prior to stimulation with Rv1016c. Levels of CIITA IV mRNA expression induced by IFN- $\gamma$ was measured by Q-PCR. As shown in Figure 7D, three inhibitors could attenuate Rv1016c-mediated inhibition of CIITA IV expression. These results indicate that Rv1016c may inhibit CIITA IV expression dependent on TLR2 and MAPK signaling.

\section{DISCUSSION}

MTB genome encodes about 100 putative lipoproteins, which may have critical functions ranging from interfering mycobacterial virulence, generating antigenic variation and evading host immune responses (Sutcliffe and Harrington, 2004). LppX is involved in the correct localization of phthiocerol dimycocerosates (PDIMs), an important virulence factor of M. tuberculosis. LprG binds triacylated phospho-inositolmannoside (PIM), lipomannan (LM) and lipoarabinomannan (LAM) involved in the inhibition of phagosome-lysosome fusion (Drage et al., 2010; Martinot et al., 2016). However, several mycobacterial lipoproteins form immunodominant antigens can promote protective immune response (Becker and Sander, 2016). Immunization with recombinant MPT83 or DNA-Mpt83 developed a strong IFN $-\gamma$ secreting CD4+ T-cell response, and significantly decreased the bacterial load in lung and spleen as compared to control mice (Chen et al., 2012). The interaction between mycobacterial lipoproteins and host cells involved Toll-like receptor 2 (Pecora et al., 2006; Chambers et al., 2010), which plays an important role in the elaboration of protective Ag processing and inflammatory cytokines (Zeytun et al., 2007; Saraav et al., 2014). As the key roles of lipoproteins and TLR2 during MTB infection, the identification of novel MTB lipoproteins, which bind to TLR2, contributes to deep understanding the interaction between the pathogen and APCs where it resides (Drage et al., 2009). In this context, we identified Rv1016c as a mycobacterial cell wall -associated lipoprotein. In addition, the affinity column pull downs using Rv1016c immobilized on Ni-NTA beads followed by western blotting analysis with anti-TLR2 antibody confirmed that Rv1016c physically interacted with TLR2. Moreover, Rv1016c could enhance the survival of the recombinant $M$. smegmatis within macrophages and promote the resistance to stress factors. Taken together, MTB lipoproteins Rv1016c may be a novel TLR2 ligand and involve mycobacterial virulence.

Mycobacteria tuberculosis has been shown to be capable of causing monocytes and alveolar macrophages apoptosis in vitro, and alveolar macrophages recovered from MTB patients also showed an increased frequency of apoptosis (Placido et al., 1997; Keane et al., 2000). Recently, considerable interest has emerged in understanding how $M$. tuberculosis infection affects apoptosis of immune cells and whether this contributes to pathogenesis. In the present study, we investigated the potential role of the cell wall-associated protein Rv1016c to induce macrophages apoptosis. Our data showed that soluble Rv1016c alone was able to induce macrophages apoptosis in a both dose- and time-dependent manner, and this effect was specific not due to the His-tag or LPS contamination. TLR2 has been shown to involve apoptosis induced by MTB ligands, and we further examined whether induction of macrophages apoptosis by Rv1016c is TLR2 dependent. The results showed that apoptosis induction by Rv1016c was abrogated in TLR2 ${ }^{-/-}$mouse macrophages or THP-1 cells treated with anti-TLR2 blocking Abs, indicating that Rv1016c may be an apoptosis-inducing factor dependent on TLR2. Taken together, Rv1195 could promote the survival of recombinant $M$. smegmatis and induce apoptosis of host cells, consistent with the effect of MTB19-kDa lipoprotein on macrophages (Lopez et al., 2003), indicating that Rv1016c-induced apoptosis may lead to mycobacterial cell-to-cell spread, and the increased survival of mycobacteria during the infection.

MHC-II molecules continuously expressed in response to infection can load with antigenic peptides in the MHC compartment, and then export to the plasma membrane, where they prime $\mathrm{CD}^{+} \mathrm{T}$ cells (Forsyth and Eisenlohr, 2016). Transcriptional control of MHC-II expression may be a molecular basis of immune surveillance, through which APC functions are regulated by $M$. tuberculosis protein during infection (Ramachandra et al., 2009). Actually, MHCII expression can be regulated by cytokines like IFN- $\gamma$ or TLRs ligands in macrophages during MTB infection (Stern and Santambrogio, 2016). Some Mycobacterial lipoproteins such as (LpqH and LprG) were found to suppress MHC-II expression via TLR2 in macrophages (Stewart et al., 2005; Shukla et al., 2014). Similarly, in this study, Rv1016c was able to inhibit IFN- $\gamma$-induced MHC-II expression and attenuated Ag processing and presentation of macrophages, as reflected by a decrease in IL-2 production (Figure 5). Additionally, Rv1016cmediated Inhibition of MHC-II expression and Ag processing was reserved in TLR2 $2^{-/-}$mouse macrophages or THP-1 cells blocked by anti-TLR2 Abs (Figure 6). Moreover, Rv1016c lipoprotein inhibited IFN- $\gamma$-induced MHC-II expression by preventing induction of class II transactivator (CIITA) IV in a TLR2 dependent mechanism (Figure 7). Together, Rv1016cmediated inhibition of MHC-II expression and Ag processing may lead to the prevention of Ag presentation and the decreased recognition by $\mathrm{CD} 4^{+} \mathrm{T}$ cells. This may provide a mechanism by which intracellular bacilli are able to evade immune surveillance, survive under stress factors and maintain chronic infection.

In this study, we find that cell wall-associated lipoprotein Rv1016c may be a novel TLR2 ligand and may involve mycobacterial virulence by enhancing survival of recombinant $M$. smegmatis within macrophages and increasing resistance to stress factors. Rv1016c may be an apoptosis-inducing factor, and able to promote mycobacterial cell-to-cell spread during infection. Moreover, we determine that Rv1016c lipoprotein may inhibit IFN- $\gamma$-induction of MHC-II expression and $\mathrm{Ag}$ processing by decreased IFN- $\boldsymbol{\gamma}$-induced CIITA IV expression via TLR2 and MAPK signaling. In the context of tuberculosis, we propose that Rv1016c lipoprotein can induce apoptosis, increase the survival of bacilli, and decrease the presentation of MTB Ag to $\mathrm{CD}^{+} \mathrm{T}$ cells 
within human macrophages, allowing intracellular $M$. tuberculosis to evade immune surveillance and promote chronic infection.

\section{AUTHOR CONTRIBUTIONS}

HS, HW, and YX conceived and designed the experiments; HS performed the experiments; HS, YX analyzed the data; HS, ZZ, HW, and YX wrote the manuscript; and HW, YX reviewed the

\section{REFERENCES}

Becker, K., and Sander, P. (2016). Mycobacterium tuberculosis lipoproteins in virulence and immunity - fighting with a double-edged sword. FEBS Lett. doi: 10.1002/1873-3468.12273. [Epub ahead of print].

Bruchfeld, J., Correia-Neves, M., and Källenius, G. (2015). Tuberculosis and HIV Coinfection. Cold Spring Harb. Perspect. Med. 5:a017871. doi: 10.1101/cshperspect.a017871

Chambers, M. A., Whelan, A. O., Spallek, R., Singh, M., Coddeville, B., Guerardel, Y., et al. (2010). Non-acylated Mycobacterium bovis glycoprotein MPB83 binds to TLR1/2 and stimulates production of matrix metalloproteinase 9. Biochem. Biophys. Res. Commun. 400, 403-408. doi: 10.1016/j.bbrc.2010.08.085

Chen, S. T., Li, J. Y., Zhang, Y., Gao, X., and Cai, H. (2012). Recombinant MPT83 derived from Mycobacterium tuberculosis induces cytokine production and upregulates the function of mouse macrophages through TLR2. J. Immunol. 188, 668-677. doi: 10.4049/jimmunol.1102177

Dalgic, N., Tekin, D., Kayaalti, Z., Soylemezoglu, T., Cakir, E., Kilic, B., et al. (2011). Arg753Gln polymorphism of the human Toll-like receptor 2 gene from infection to disease in pediatric tuberculosis. Hum. Immunol. 72, 440-445. doi: 10.1016/j.humimm.2011.02.001

Dao, D. N., Kremer, L., Guérardel, Y., Molano, A., Jacobs, W. R. Jr., Porcelli, S. A., et al. (2004). Mycobacterium tuberculosis lipomannan induces apoptosis and interleukin-12 production in macrophages. Infect. Immun. 72, 2067-2074. doi: 10.1128/IAI.72.4.2067-2074.2004

De Lerma Barbaro, A., Tosi, G., Valle, M. T., Megiovanni, A. M., Sartoris, S., D'Agostino, A., et al. (1999). Distinct regulation of HLA class II and class I cell surface expression in the THP-1 macrophage cell line after bacterial phagocytosis. Eur. J. Immunol. 29, 499-511.

Derrick, S. C., and Morris, S. L. (2007). The ESAT6 protein of Mycobacterium tuberculosis induces apoptosis of macrophages by activating caspase expression. Cell. Microbiol. 9, 1547-1555. doi: 10.1111/j.1462-5822.2007.00892.x

Dheda, K., Barry, C. E. III, and Maartens, G. (2016). Tuberculosis. Lancet 387, 1211-1226. doi: 10.1016/S0140-6736(15)00151-8

Dorhoi, A., and Kaufmann, S. H. (2014). Perspectives on host adaptation in response to Mycobacterium tuberculosis: modulation of inflammation. Semin. Immunol. 26, 533-542. doi: 10.1016/j.smim.2014.10.002

Drage, M. G., Pecora, N. D., Hise, A. G., Febbraio, M., Silverstein, R. L., Golenbock, D. T., et al. (2009). TLR2 and its co-receptors determine responses of macrophages and dendritic cells to lipoproteins of Mycobacterium tuberculosis. Cell. Immunol. 258, 29-37. doi: 10.1016/j.cellimm.2009. 03.008

Drage, M. G., Tsai, H. C., Pecora, N. D., Cheng, T. Y., Arida, A. R., Shukla, S., et al. (2010). Mycobacterium tuberculosis lipoprotein LprG (Rv1411c) binds triacylated glycolipid agonists of Toll-like receptor 2. Nat. Struct. Mol. Biol. 17, 1088-1095. doi: 10.1038/nsmb.1869

Forsyth, K. S., and Eisenlohr, L. C. (2016). Giving CD4+ T cells the slip: viral interference with MHC class II-restricted antigen processing and presentation. Curr. Opin. Immunol. 40, 123-129. doi: 10.1016/j.coi.2016.03.003

Gomes, M. S., Flórido, M., Cordeiro, J. V., Teixeira, C. M., Takeuchi, O., Akira, S., et al. (2004). Limited role of the Toll-like receptor-2 in resistance to Mycobacterium avium. Immunology 111, 179-185. doi: 10.1111/j.00192805.2003.01807.x

Harding, C. V., and Boom, W. H. (2010). Regulation of antigen presentation by Mycobacterium tuberculosis: a role for Toll-like receptors. Nat. Rev. Microbiol. 8, 296-307. doi: 10.1038/nrmicro2321 manuscript and supervised the research. All authors read and approved the final manuscript.

\section{ACKNOWLEDGMENTS}

This work was supported by grants from the NSF of China (31600747); the National Major Special Projects (2012ZX10003008); and the NSF of Shanghai Sci. Tech. Committee (11ZR1401600).

Holvast, A., de Haan, A., van Assen, S., Stegeman, C. A., Huitema, M. G. Huckriede, A., et al. (2010). Cell-mediated immune responses to influenza vaccination in Wegener's granulomatosis. Ann. Rheum. Dis. 69, 924-927. doi: 10.1136/ard.2009.112813

Jasenosky, L. D., Scriba, T. J., Hanekom, W. A., and Goldfeld, A. E. (2015). T cells and adaptive immunity to Mycobacterium tuberculosis in humans. Immunol. Rev. 264, 74-87. doi: 10.1111/imr.12274

Kaufmann, E., Spohr, C., Battenfeld, S., De Paepe, D., Holzhauser, T., Balks, E., et al. (2016). BCG vaccination induces robust CD4+ $\mathrm{T}$ cell responses to Mycobacterium tuberculosis Complex-Specific Lipopeptides in Guinea Pigs. J. Immunol. 196, 2723-2732. doi: 10.4049/jimmunol.1502307

Kaufmann, S. H., and Schaible, U. E. (2005). Antigen presentation and recognition in bacterial infections. Curr. Opin. Immunol. 17, 79-87. doi: 10.1016/j.coi.2004.12.004

Keane, J., Remold, H. G., and Kornfeld, H. (2000). Virulent Mycobacterium tuberculosis strains evade apoptosis of infected alveolar macrophages. J. Immunol. 164, 2016-2020. doi: 10.4049/jimmunol.164.4.2016

Kleinnijenhuis, J., Oosting, M., Joosten, L. A., Netea, M. G., and Van Crevel, R. (2011). Innate immune recognition of Mycobacterium tuberculosis. Clin. Dev. Immunol. 2011:405310. doi: 10.1155/2011/405310

Li, H., Li, Q., Yu, Z., Zhou, M., and Xie, J. (2016). Mycobacterium tuberculosis PE13 (Rv1195) manipulates the host cell fate via p38-ERK-NF- $\kappa$ B axis and apoptosis. Apoptosis 21, 795-808. doi: 10.1007/s10495-016-1249-y

López, M., Sly, L. M., Luu, Y., Young, D., Cooper, H., and Reiner, N. E. (2003). The 19-kDa Mycobacterium tuberculosis protein induces macrophage apoptosis through Toll-like receptor-2. J. Immunol. 170, 2409-2416. doi: 10.4049/jimmunol.170.5.2409

Martinot, A. J., Farrow, M., Bai, L., Layre, E., Cheng, T. Y., Tsai, J. H., et al. (2016) Mycobacterial metabolic syndrome: LprG and Rv1410 regulate triacylglyceride levels, growth rate and virulence in Mycobacterium tuberculosis. PLoS Pathog. 12:e1005351. doi: 10.1371/journal.ppat.1005351

Means, T. K., Jones, B. W., Schromm, A. B., Shurtleff, B. A., Smith, J. A., Keane, J., et al. (2001). Differential effects of a Toll-like receptor antagonist on Mycobacterium tuberculosis-induced macrophage responses. J. Immunol. 166, 4074-4082. doi: 10.4049/jimmunol.166.6.4074

Noss, E. H., Harding, C. V., and Boom, W. H. (2000). Mycobacterium tuberculosis inhibits MHC class II antigen processing in murine bone marrow macrophages. Cell. Immunol. 201, 63-74. doi: 10.1006/cimm.2000.1633

Noss, E. H., Pai, R. K., Sellati, T. J., Radolf, J. D., Belisle, J., Golenbock, D. T., et al. (2001). Toll-like receptor 2-dependent inhibition of macrophage class II MHC expression and antigen processing by $19-\mathrm{kDa}$ lipoprotein of Mycobacterium tuberculosis. J. Immunol. 167, 910-918. doi: 10.4049/jimmunol.167.2.910

Ogus, A. C., Yoldas, B., Ozdemir, T., Uguz, A., Olcen, S., Keser, I., et al. (2004). The Arg753GLn polymorphism of the human toll-like receptor 2 gene in tuberculosis disease. Eur. Respir. J. 23, 219-223. doi: 10.1183/09031936.03.00061703

Pai, R. K., Convery, M., Hamilton, T. A., Boom, W. H., and Harding, C. V. (2003). Inhibition of IFN-gamma-induced class II transactivator expression by a 19 $\mathrm{kDa}$ lipoprotein from Mycobacterium tuberculosis: a potential mechanism for immune evasion. J. Immunol. 171, 175-184. doi: 10.4049/jimmunol.171.1.175

Pecora, N. D., Fulton, S. A., Reba, S. M., Drage, M. G., Simmons, D. P., Urankar-Nagy, N. J., et al. (2009). Mycobacterium bovis BCG decreases MHC-II expression in vivo on murine lung macrophages and dendritic cells during aerosol infection. Cell. Immunol. 254, 94-104. doi: 10.1016/j.cellimm.2008.07.002 
Pecora, N. D., Gehring, A. J., Canaday, D. H., Boom, W. H., and Harding, C. V. (2006). Mycobacterium tuberculosis LprA is a lipoprotein agonist of TLR2 that regulates innate immunity and APC function. J. Immunol. 177, 422-429. doi: 10.4049/jimmunol.177.1.422

Pennini, M. E., Pai, R. K., Schultz, D. C., Boom, W. H., and Harding, C. V. (2006). Mycobacterium tuberculosis 19-kDa lipoprotein inhibits IFN-gamma-induced chromatin remodeling of MHC2TA by TLR2 and MAPK signaling. J. Immunol. 176, 4323-4330. doi: 10.4049/jimmunol.176.7.4323

Placido, R., Mancino, G., Amendola, A., Mariani, F., Vendetti, S., Piacentini, M., et al. (1997). Apoptosis of human monocytes/macrophages in Mycobacterium tuberculosis infection. J. Pathol. 181, 31-38.

Ramachandra, L., Simmons, D., and Harding, C. V. (2009). MHC molecules and microbial antigen processing in phagosomes. Curr. Opin. Immunol. 21, 98-104. doi: 10.1016/j.coi.2009.01.001

Reiling, N., Hölscher, C., Fehrenbach, A., Kröger, S., Kirschning, C. J., Goyert, S., et al. (2002). Cutting edge: toll-like receptor (TLR)2- and TLR4-mediated pathogen recognition in resistance to airborne infection with Mycobacterium tuberculosis. J. Immunol. 169, 3480-3484. doi: 10.4049/jimmunol.169.7.3480

Richardson, E. T., Shukla, S., Sweet, D. R., Wearsch, P. A., Tsichlis, P. N., Boom, W. H., et al. (2015). Toll-like receptor 2-dependent extracellular signal-regulated kinase signaling in Mycobacterium tuberculosis-infected macrophages drives anti-inflammatory responses and inhibits Th1 polarization of responding $\mathrm{T}$ cells. Infect. Immun. 83, 2242-2254. doi: 10.1128/IAI.00135-15

Sanchez, A., Espinosa, P., Esparza, M. A., Colon, M., Bernal, G., and Mancilla, R. (2009). Mycobacterium tuberculosis $38-\mathrm{kDa}$ lipoprotein is apoptogenic for human monocyte-derived macrophages. Scand. J. Immunol. 69, 20-28. doi: 10.1111/j.1365-3083.2008.02193.x

Saraav, I., Singh, S., and Sharma, S. (2014). Outcome of Mycobacterium tuberculosis and Toll-like receptor interaction: immune response or immune evasion? Immunol. Cell Biol. 92, 741-746. doi: 10.1038/icb.2014.52

Satchidanandam, V., Kumar, N., Jumani, R. S., Challu, V., Elangovan, S., and Khan, N. A. (2014). The glycosylated Rv1860 protein of Mycobacterium tuberculosis inhibits dendritic cell mediated TH1 and TH17 polarization of T cells and abrogates protective immunity conferred by BCG. PLoS Pathog. 10:e1004176. doi: 10.1371/journal.ppat.1004176

Shi, C., Yuan, S., Zhang, H., Zhang, T., Wang, L., and Xu, Z. (2009). Cellmediated immune responses and protective efficacy against infection with Mycobacterium tuberculosis induced by Hsp65 and hIL-2 fusion protein in mice. Scand. J. Immunol. 69, 140-149. doi: 10.1111/j.1365-3083.2008.02207.x

Shukla, S., Richardson, E. T., Athman, J. J., Shi, L., Wearsch, P. A., McDonald, D., et al. (2014). Mycobacterium tuberculosis lipoprotein LprG binds lipoarabinomannan and determines its cell envelope localization to control phagolysosomal fusion. PLoS Pathog. 10:e1004471. doi: 10.1371/journal.ppat.1004471

Stern, L. J., and Santambrogio, L. (2016). The melting pot of the MHC II peptidome. Curr. Opin. Immunol. 40, 70-77. doi: 10.1016/j.coi.2016. 03.004

Stewart, G. R., Wilkinson, K. A., Newton, S. M., Sullivan, S. M., Neyrolles, O., Wain, J. R., et al. (2005). Effect of deletion or overexpression of the 19-kilodalton lipoprotein Rv3763 on the innate response to Mycobacterium tuberculosis. Infect. Immun. 73, 6831-6837. doi: 10.1128/IAI.73.10.6831-6837.2005

Su, H., Kong, C., Zhu, L., Huang, Q., Luo, L., Wang, H., et al. (2015). PPE26 induces TLR2-dependent activation of macrophages and drives Th1-type T-cell immunity by triggering the cross-talk of multiple pathways involved in the host response. Oncotarget 6, 38517-38537. doi: 10.18632/oncotarget.5956

Sutcliffe, I. C., and Harrington, D. J. (2004). Lipoproteins of Mycobacterium tuberculosis: an abundant and functionally diverse class of cell envelope components. FEMS Microbiol. Rev. 28, 645-659. doi: 10.1016/j.femsre.2004.06.002

Texereau, J., Chiche, J. D., Taylor, W., Choukroun, G., Comba, B., and Mira, J. P. (2005). The importance of Toll-like receptor 2 polymorphisms in severe infections. Clin. Infect. Dis. 41(Suppl. 7), S408-S415. doi: 10.1086/431990

Torrado, E., and Cooper, A. M. (2011). What do we really know about how CD4 T cells control Mycobacterium tuberculosis? PLoS Pathog. 7:e1002196. doi: 10.1371/journal.ppat.1002196

Xu, Y., Yang, E., Huang, Q., Ni, W., Kong, C., Liu, G., et al. (2015). PPE57 induces activation of macrophages and drives Th1-type immune responses through TLR2. J. Mol. Med. 93, 645-662. doi: 10.1007/s00109-014-1243-1

Zeytun, A., van Velkinburgh, J. C., Pardington, P. E., Cary, R. R., and Gupta, G. (2007). Pathogen-specific innate immune response. Adv. Exp. Med. Biol. 598 342-357. doi: 10.1007/978-0-387-71767-8_24

Conflict of Interest Statement: The authors declare that the research was conducted in the absence of any commercial or financial relationships that could be construed as a potential conflict of interest.

Copyright (c) $2016 \mathrm{Su}, \mathrm{Zhu}, \mathrm{Zhu}$, Huang, Wang, Zhang and Xu. This is an open-access article distributed under the terms of the Creative Commons Attribution License (CC $B Y)$. The use, distribution or reproduction in other forums is permitted, provided the original author(s) or licensor are credited and that the original publication in this journal is cited, in accordance with accepted academic practice. No use, distribution or reproduction is permitted which does not comply with these terms. 